\title{
Cuticle ultrastructure in Brachyphyllum garciarum sp. nov (Lower Cretaceous, Argentina) reveals its araucarian affinity
}

\author{
Martin A. Carrizo ${ }^{\text {a,* }}$, Maiten A. Lafuente Diaz ${ }^{\text {a }}$, Georgina M. Del Fueyo a , Gaëtan Guignard ${ }^{\text {b }}$ \\ a División Paleobotánica, Museo Argentino de Ciencias Naturales “Bernardino Rivadavia”, CONICET. Av. Ángel Gallardo 470, 1405 Buenos Aires, Argentina \\ b Université Lyon 1, CNRS, UMR 5023 LEHNA, 7-9 rue Raphaël Dubois, Villeurbanne cedex F-69622, Lyon, France
}

\section{A R T I C L E I N F O}

\section{Article history:}

Received 28 February 2019

Received in revised form 14 June 2019

Accepted 19 June 2019

\section{Keywords:}

Foliar cuticle

Ultrastructure

Taxonomy

Brachyphyllum

Lower Cretaceous

Patagonia

\begin{abstract}
A B S T R A C T
A detailed and extensive study of a new species, Brachyphyllum garciarum sp. nov., was carried out through the analysis of the gross morphology and the cuticle fine details, structure and ultrastructure characters of its leaves using light microscope and scanning and transmission electron microscope. The fossils consist of compressions of incomplete twigs with well-preserved cuticle, collected from pelitic levels of the Springhill Formation (lower Hauterivian/lower Barremian) at the Río Correntoso locality in the Santa Cruz province, Argentina. The twigs have adpressed scale-like leaves spirally disposed. Leaves have a rhomboidal to pyramidal shape, a width and length always in a 1:1 ratio, margin entire and apex mostly rounded. Leaves are amphistomatic with stomatal apparatuses occurring in groups of narrow-wedge shape along the leaf axis. Stomatal apparatuses are close to each other with subsidiary cells in contact; the guard cells are sunken, with marked polar extensions and thickened mouth. Remnants of hypodermis cells are present in both foliar epidermis. Ultrastructurally, four types of cuticles were observed and evaluated statistically in detail: the ordinary epidermal cell upper and lower cuticles and the subsidiary cell cuticle are compounded of A2 granular layer and a spongy B1 layer somewhat mixed with cell wall remnants, while the guard cell cuticle presents only a spongy B1 layer. An Energy Dispersive Spectroscopy study was also made revealing the presence of 10 characteristic ratios with taxonomic importance, at least at the species level: $\mathrm{N} / \mathrm{Na}, \mathrm{S} / \mathrm{Cl}, \mathrm{S} / \mathrm{Na}, \mathrm{Cl} / \mathrm{K}, \mathrm{K} / \mathrm{Na}$ as the most important; followed by N/Ca, S/K, Cl/Ca, Cl/Na; and S/Ca being the least reliable. The combination of morphological and cuticle ultrastructure features of Brachyphyllum garciarum sp. nov. are unique and clearly different from other contemporary species of the genus from Western Gondwana. Moreover, the ultrastructure of the foliar cuticle suggests a highly probable affinity with the Araucariaceae Family, more precisely with the genus Araucaria. Of the four recognized sections among the living species of Araucaria, the leaf morphology of B. garciarum sp. nov. is mostly similar with some species of the Eutacta section.
\end{abstract}

(C) 2019 Elsevier B.V. All rights reserved.

\section{Introduction}

The genus Brachyphyllum (Lindley \& Hutton) Harris includes coniferous branches with scale-like leaves spirally disposed. The leaves have typically width to length ratios of $1: 1$, a rhomboidal to hexagonal foliar base and, depending on the species, can either be adpressed to the stem or have the distal portion separated from the stem at different angles. However, this type of leaf morphology is present in at least four conifer families, Araucariaceae, Cheirolepidiaceae, Cupressaceae and Podocarpaceae. Small branches with leaves of the Brachyphyllum type have been found in connection with megasporangiate cones or bractscale complexes of the Araucariaceae family, as is the case of

\footnotetext{
* Corresponding author at: Av. Ángel Gallardo 470, 1405 Buenos Aires, Argentina. E-mail addresses: blackdisk@gmail.com (M.A. Carrizo),guignard@univ-lyon1.fr (G. Guignard).
}

B. mamillare from the Jurassic of Yorkshire (Harris, 1979). Also, within this family, Del Fueyo (1991) described Nothopehuen brevis, from the Cretaceous of Santa Cruz, Argentina, where microsporangiate cones with pollen grains of the Araucariacites type were found organically attached to twigs with leaves of the Brachyphyllum type. In addition, Del Fueyo et al. (2008) studied megasporangiate cones of Kachaikestrobus acuminatus, with reproductive features similar to those of the Cheirolepidiaceae from the Cretaceous of Argentina, that have organic connection with branches with leaves of the Brachyphyllum type. These kinds of leaves are also present in a few Cretaceous taxa from Patagonia belonging to the Cupressaceae and Podocarpaceae, such as the cases of Athrotaxis ungeri and Squamastrobus tigrensis, respectively (Archangelsky, 1963; Archangelsky and Del Fueyo, 1989). Therefore, the occurrence of fossil species with leaves of Brachyphyllum type in different conifer families makes uncertain the systematic allocation of these taxa unless reproductive structures (seed cones or pollen cones) are found in organic connection. 
In this contribution, the foliar morphology and cuticle ultrastructure of leaves of the Brachyphyllum type, recovered from the Lower Cretaceous Springhill Formation at the Río Correntoso locality in the Santa Cruz province, Argentina, is fully characterized with the aid of light and electron (scanning and transmission) microscopy and through an Energy Dispersive Spectroscopy analysis. All these studies turned to be of taxonomic importance revealing the probable affinity of these Brachyphyllum leaves and highlighting the foliar differences with other contemporary species of the genus from Western Gondwana allowing the erection of a new Patagonian taxon.

\section{Geological and paleobotanical background}

The Springhill Formation (Thomas, 1949) occurs in the NNW sector of the Austral Basin, covering the south of Argentina and Chile. In Argentina, deposits of this Formation are widely distributed. They crop out on the NE coast of Pueyrredón Lake; in the vicinity of the Estancia Bella Vista locality; near the Ghío Lake and close to the Salitroso Lake, in the Santa Cruz province, and characterize the subsurface of the Tierra del Fuego province and the Continental Platform of the Argentine Sea. However, the thickness of the Springhill Formation is laterally variable and thus, this lithostratigraphic unit is partially to completely absent in certain areas, especially in Santa Cruz (Nullo et al., 1999; Arbe, 2002; Poiré et al., 2011).

The Springhill Formation consists of continental deposits overlain by marine sediments, recording, on the whole, a transgressive trend in the facies evolution. Due to the wide areal extension and the transgressive nature of the deposits, the Springhill Formation is a heterochronic unit, whose older deposits occur in the southern areas, while the younger ones are found towards the north. Therefore, the age of this lithostratigraphic unit is Valanginian/Hauterivian and Berriasian?/ Valanginian-lower Hauterivian in the subsurface of Chile, Tierra del Fuego and the Continental Platform of Argentina, and late lower Hauterivian/lower Barremian at the proximities of the Estancia El Salitral locality (Riccardi, 1976; Cortiñas and Arbe, 1981; Archangelsky et al., 1984; Ottone and Aguirre-Urreta, 2000; Giacosa and Franchi, 2001; Archangelsky and Archanglelsky, 2004; Spalletti et al., 2009).

The knowledge of the plant assemblage of the Springhill Formation has been extended recently with the discovery of new megafossils. Most of these new recovered materials present well-preserved cuticles that made possible to find their unequivocal taxonomic placement (Carrizo and Del Fueyo, 2015; Carrizo et al., 2019). This plant community is dominated by the Cycadophyta, with about $50 \%$ of the total diversity, from which the Bennettitales (46\%) predominate over the Cycadales (4\%). The second most abundant group corresponds to the Pinophyta (20\%), and includes several leafy twigs of Brachyphyllum, Elatocladus, and bract-scale complexes referred to the Eutacta Section of the genus Araucaria. In Argentina, the fossil record of Brachyphyllum during the Early Cretaceous includes B. kachaikensis Passalia, from the Piedra Clavada Formation in the locality of San Martin Lake; B. mucronatum Archangelsky, B. mirandai Archangelsky, B. irregulare Archangelsky, B. brettii Archangelsky, B. baqueroense Traverso and $B$. tigrense Traverso from the Baqueró Group, in the locality of Anfiteatro de Ticó; and Brachyphyllum feistmantelii (Halle) Sahni, found in core samples from Southern Chile (Archangelsky, 1963; Traverso, 1966, 1968; Archangelsky, 1976; Baldoni, 1979; Passalia, 2007; Carrizo and Del Fueyo, 2015).

\section{Material and methods}

The fossils herein described include compressions of incomplete twigs bearing leaves with well-preserved cuticles, collected from pelitic levels of the Springhill Formation outcropping at the Río Correntoso locality, Santa Cruz province, Argentina (Fig. 1).

The extraction of cuticle from the rock was made using entomological needles and soft hair brushes to gently remove the organic material from the sediment. The recovered cuticles were then treated with $40 \%$ nitric acid followed by $5 \%$ ammonium hydroxide and cleared with sodium hypochlorite. When the inorganic material and the carbonized mesophyll were hard to disaggregate, the leaves were instead macerated in hydrochloric acid (20\%) followed by hydrofluoric acid (70\%), while all the remnants of carbonized mesophyll were removed using $5 \mathrm{~s}$ of ultrasound.

For the observations made with light microscopy (LM), the cuticles were stained with safranin and mounted in glycerin jelly, whereas for scanning electron microscopy (SEM) observations, the cleaned cuticles were mounted on exposed film, glued to stubs and coated with gold-palladium. Each of the morphological and epidermal features were measured using at least an $\mathrm{n}>20$. Light microscopy observations were made with a Leica DM 2500 microscope and the micrographs were taken with a Leica DFC 280 and a Leica ICC50 camera. SEM observations were made under a Philips XL30 TMP SEM at $15.1 \mathrm{kV}$ at the Museo Argentino de Ciencias Naturales "Bernardino Rivadavia."

The samples for transmission electron microscopy (TEM) were prepared following Lugardon's technique (Lugardon, 1971), also used for living plant cuticles (conifers and angiosperms; Bartiromo et al., 2012, 2013). In total, six pieces were embedded in Epon resin: three blocks were made from three treated samples; three blocks from three untreated samples. From these, 300 ultrathin 60-70 nm thick uncoated sections were made: 210 for untreated sample (170 were mounted on 300 Mesh copper grids, 20 with 75 Mesh hexagonal copper grids, 20 with single slot Nickel or copper grids) and 90 for treated sample collected on uncoated 300 Mesh copper grids. Of the sections, 270 are transversal, i.e. perpendicular to the leaf length, while 30 are longitudinal, i.e. parallel to the leaf length. Ultrathin sections were selected, observed and photographed with a Philips CM 120 at $80 \mathrm{kV}$, at the Centre de Technologie des Microstructures (CT $\mu$ ) of Lyon-1 University, France.

In order to check for chemical elements the Energy Dispersive Spectroscopy (EDS) analyses was performed on the TEM using SIRIUS SD ENSOTECH coupled with IDFIX software, acceleration voltage $120 \mathrm{kV}$, spot sizes $1-3$, processing time $120 \mathrm{~s}$, constant of time 4 $\mu \mathrm{s}$. From the untreated material, 25 uncoated grids were made (10 with 300 Mesh copper grids, 5 with hexagonal 75 Mesh copper grids, 10 with single slot Nickel or copper grids), all devoid of uranyl acetate and lead citrate staining. Among available chemical elements, $\mathrm{Cu}$ and $\mathrm{Al}$ were not considered in the results as belonging to the grid, Os is part of the embedding technique, $\mathrm{Si}$ is part of the oils used in the TEM and $\mathrm{C}$ and $\mathrm{O}$ are also major parts of the EPON embedding resin. Of the remaining chemical elements, measurements ( 5 for each check) were evaluated with the Mann Withney test, using XLSTAT version 2018.2 software, providing diagrams of the results included in this paper. The EDS was also performed through SEM, enabling the comparisons and locations of the chemical elements obtained with EDS by TEM using three resin blocks of untreated material used for TEM sections, $10 \mathrm{~nm}$ of thickness carbon-coated, with a BALZERS MED010. SEM is a Zeiss Merlin compact $10 \mathrm{kv}$, where EDS analysis is using Oxford X-max $50 \mathrm{~mm} 2$, AZTEC software. For TEM and EDS statistics, XLSTAT 2019.1 was used (Addinsoft (2019). XLSTAT statistical and data analysis solution. Long Island, NY, USA. https://www.xlstat.com.)

All the samples of Brachyphyllum garciarum sp. nov. are deposited in the Paleobotany Collection of the Regional Museum Padre M.J. Molina (MPM), Río Gallegos, Santa Cruz province, Argentina, under the acronym MPM-PB.

The following terms and abbreviations are used in most parts of the text where it is relevant as in the tables, figures and appendices: $\mathrm{OEC}=$ ordinary epidermal cell cuticle; SC and GC = subsidiary cell and guard cell, respectively; $\mathrm{CM}=$ cuticular membrane $(\mathrm{CP}+\mathrm{CL})$; $\mathrm{CP}=$ cuticle proper $(\mathrm{A}=\mathrm{A} 2$ granular layer $) ; \mathrm{CL}=$ cuticular layer $(\mathrm{B}=\mathrm{B} 1$ fibrilous layer). 

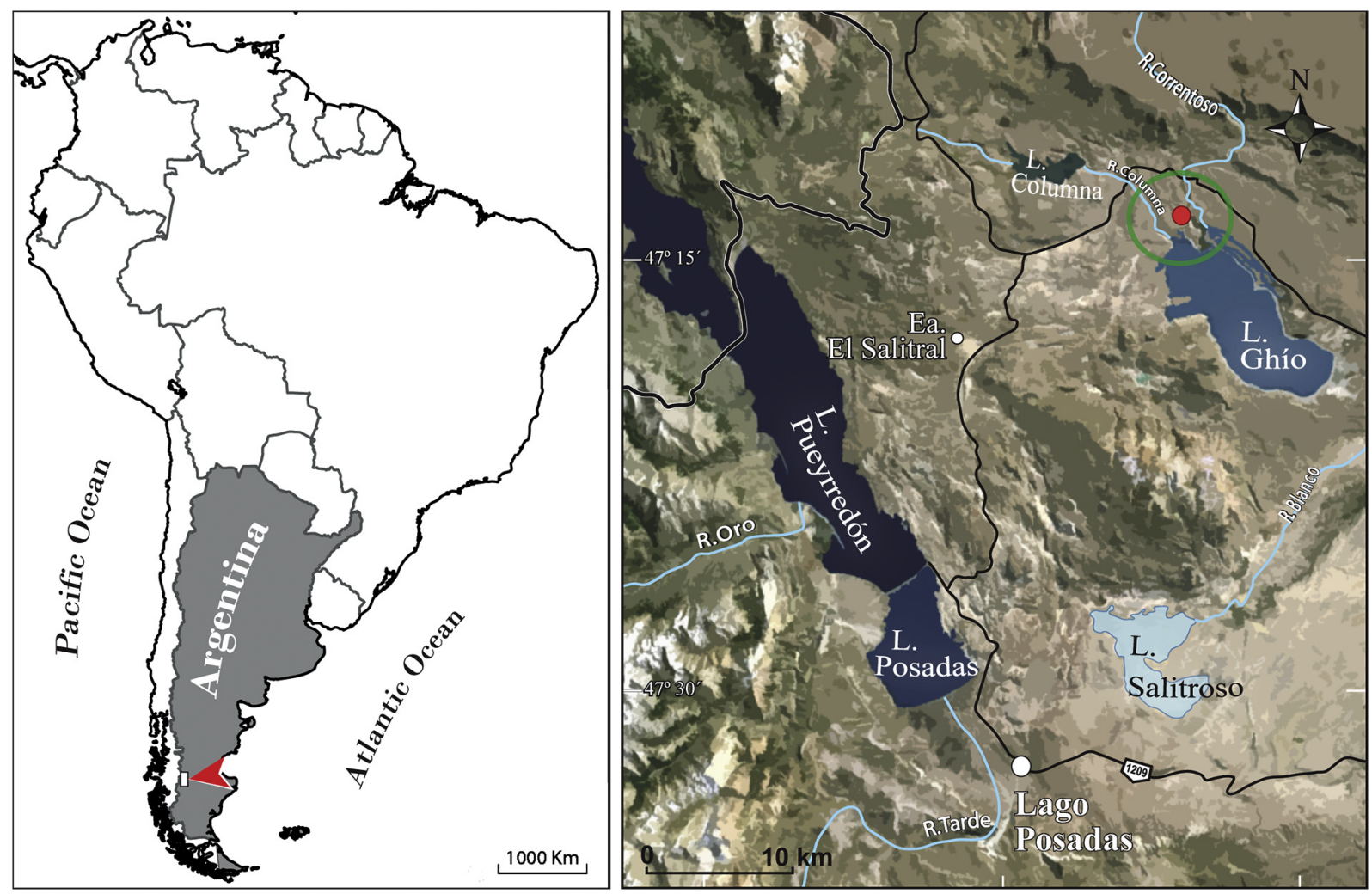

Fig. 1. Location map of the Springhill Formation outcrops, at the Río Correntoso locality Santa Cruz province, Argentina.

\section{Description and results}

\subsection{Systematic paleobotany}

Division: PINOPHYTA Cronquist, Takhtajan et Zimmermann, 1966 Order: CONIFERALES Taylor, Taylor et Krings, 2009

Family:? ARAUCARIACEAE

Genus: Brachyphyllum (Lindley et Hutton) Harris, 1979

Type species: Brachyphyllum mamillare Lindley et Hutton, 1836

Brachyphyllum garciarum sp. nov. Carrizo, Del Fueyo, Lafuente Diaz et Guignard

Plates I-XI

Derivation of the name: The specific epithet refers to the owners of Estancia El Salitral, Élida and Sebastián Garcia, who kindly let us prospect the Springhill Formation outcropping in their land.

Holotype: MPM-PB 15476

Paratypes: MPM-PB 15477-15478

Synonym:

2015 Brachyphyllum sp., Carrizo and Del Fueyo, pp. 102, 107, fig. 8 $(6,7)$.

Locality and stratigraphy horizon: Río Correntoso, Santa Cruz province, Argentina. Springhill Formation, lower Hauterivian/lower Barremian.

Diagnosis: Twigs with scale-like leaves spirally disposed, adpressed at the base. Leaves with rhomboidal to pyramidal shape; margin entire; apex mostly rounded. Base rhomboidal to oval; with a width and length always in 1:1 ratio. Abaxial epidermis slightly bigger than the adaxial, with a marked keel showing short cuticular striations. Possibly simple small trichomes along the keel. Ordinary epidermis cells mostly quadrangular to rectangular. Leaves amphistomatic. Stomatal apparatuses in rows within longitudinal narrow-wedge shape bands. Stomatal apparatuses very close to each other; stomatal pits orientated parallel to oblique and transverse to leaf axis. Stomatal apparatus oval to circular, monocyclic, with four to six subsidiary cells radially placed. Guard cells sunken with thickened mouth pit and marked polar extensions.
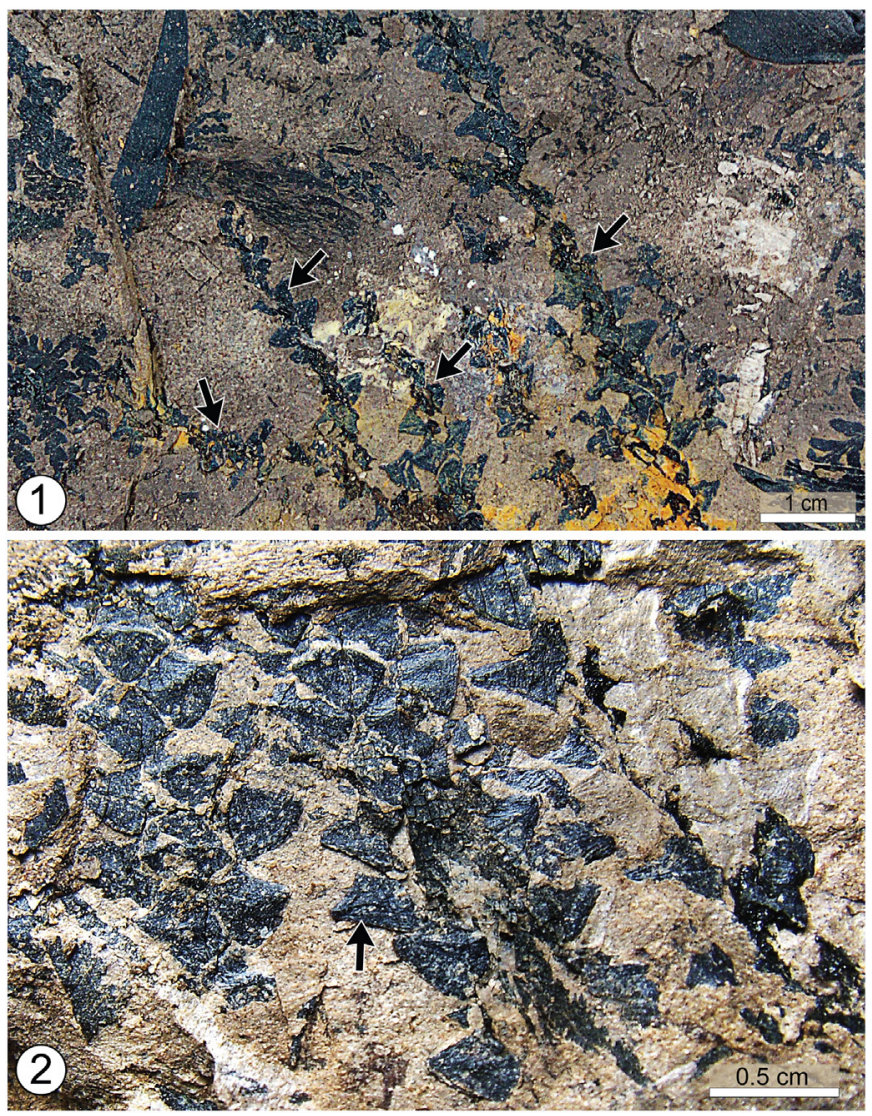

Plate I. Brachyphyllum garciarum sp. nov. 1. General aspect of the leafy twigs (arrows) MPM-PB 15477. 2. Detail of 1 showing scale-like leaves (arrow). MPM-PB 15476. 


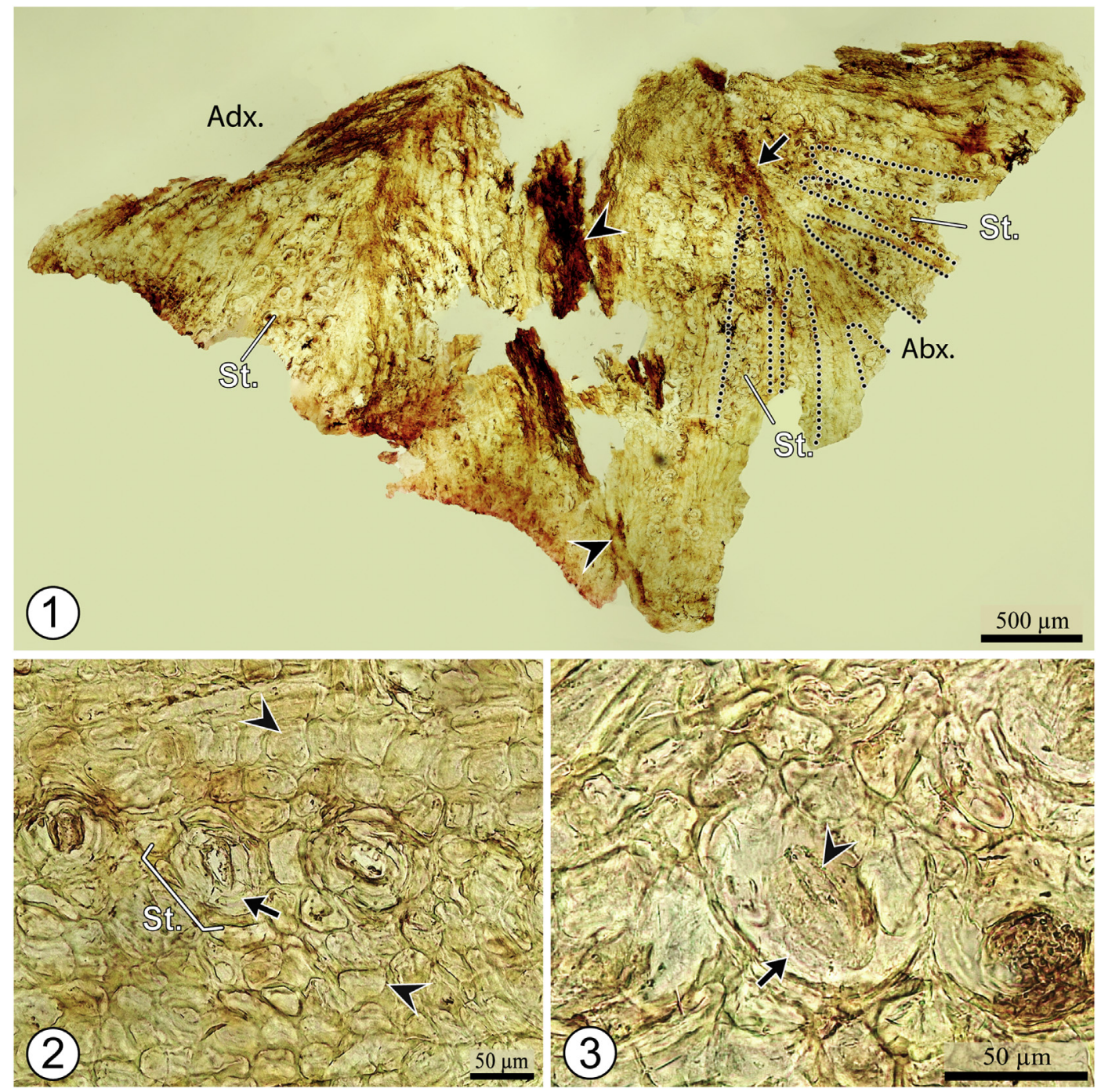

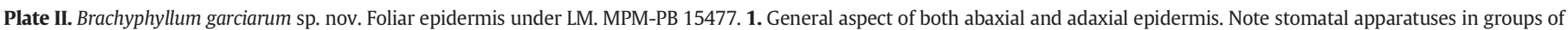

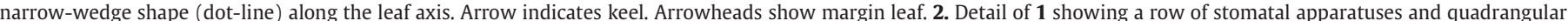

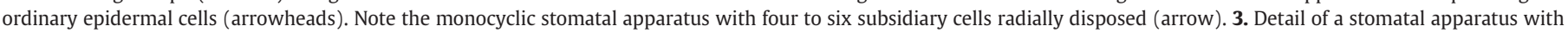
subsidiary cells (arrow) and occlusive cells with thickened mouth pit (arrowhead). Abx.: Abaxial epidermis; Adx.: Adaxial epidermis; St.: Stomatal apparatus.

Ultrastructurally, OEC upper and lower cuticles and subsidiary cell cuticle present an A2 granular layer and a B1spongy layer. Guard cell cuticle made only of B1 spongy layer.

Description:

Gross morphology and epidermal structure

The studied material consists of incomplete twigs up to $10 \mathrm{~cm}$ long and $\sim 0.7 \mathrm{~cm}$ wide with scale-like leaves spirally disposed (Plate I). Leaves are adpressed to the twigs by a rhomboidal to oval base $3.35 \mathrm{~mm}$ wide, with a free distal portion of the leaf $2.6-3 \mathrm{~mm}$ long. The leaves are rhomboidal to pyramidal in shape; with a length and width of $0.3 \mathrm{~cm}$ in mean and always in a ratio of $1: 1$. The margin is entire and the apex is mostly rounded. The length of the foliar base is difficult to measure due to compression of both epidermis.

The abaxial epidermis is slightly longer $(0.3 \mathrm{~cm}$ in mean $)$ than the adaxial epidermis ( $0.25 \mathrm{~cm}$ in mean), and shows a marked keel that probably corresponds to the vascular bundle (Plate II, 1; Plate III, 1,2). Short cuticular striations are oriented mostly perpendicular to the keel (Plate III, 2). Isolated groups of simple small trichomes of $11.5 \mu \mathrm{m}$ width are located along the keel (Plate III, 3 ).

Leaves are amphistomatic, with stomatal apparatuses grouped in narrow-wedge shape longitudinal bands disposed along the leaf axis (Plate IV, 1-3). In each band, one to three rows of stomatal apparatuses are observed, increasing the number of rows from the apex to the base of the leaf. The rows are mostly well-defined near the apex, becoming ill defined towards the foliar base. Each band is separated by 2-7 rows of ordinary epidermal cells (Plate IV, 3 ). The stomatal apparatuses are placed very close to each other; usually with subsidiary cells in contact, especially near the foliar apex (Plate IV, 5). The stomatal density is 50 per $\mathrm{mm}^{2}$, with a higher concentration on the abaxial epidermis than on the adaxial epidermis where it is about 40 per $\mathrm{mm}^{2}$. The orientation of the stomatal pits varies from parallel to oblique. The stomatal apparatus is oval to circular, with a diameter of 50-70 $\mu \mathrm{m}$ near the apex and 66-99 $\mu \mathrm{m}$ near the base (Plate II, 2,3; Plate III, 4-6). Stomatal apparatuses are monocyclic, with four to six subsidiary cells, rarely eight, radially placed, mostly quadrangular to isodiametric of 21.8-38.25 $\mu \mathrm{m}$ long and $17.45-28.5 \mu \mathrm{m}$ wide, forming an epistomatal chamber of $\sim 30.85 \mu \mathrm{m}$ long (Plate III, 4-6). The anticlinal walls of the subsidiary cells are straight to slightly curve and $\sim 0.75 \mu \mathrm{m}$ thick; the periclinal walls are smooth. The guard cells are sunken, rectangular and with polar extensions (Plate IV, 4,5). Each guard cell is 25.3-66 $\mu \mathrm{m}$ long and 8.8-17.8 $\mu \mathrm{m}$ wide; the mouth pit has a length of $15.5-30 \mu \mathrm{m}$ and shows a cuticular thickening of $1.04 \mu \mathrm{m}$ thick (Plate IV, 4,5).

The ordinary epidermal cells have the same features in both abaxial and adaxial surfaces. They are quadrangular to rectangular near the 

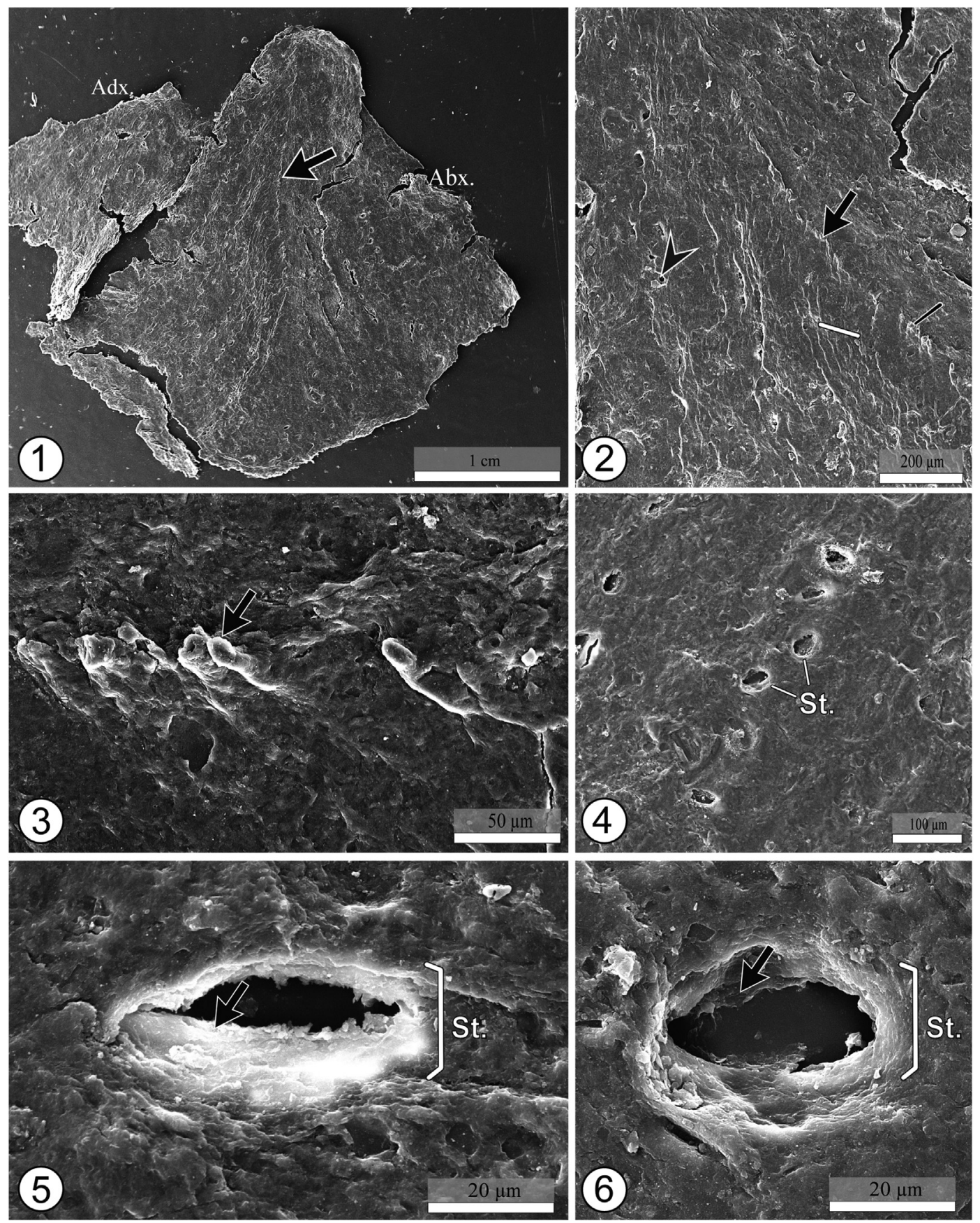

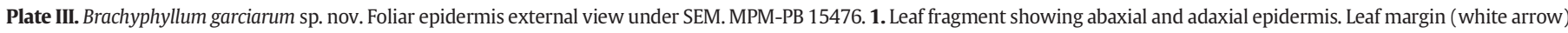

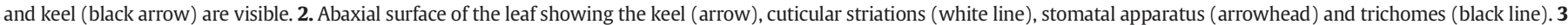

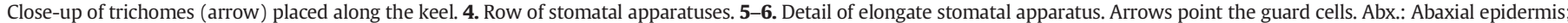
Adx.: Adaxial epidermis; St.: Stomatal apparatus.

apex and in the middle part of the foliar blade, with a mean of $37.3 \mu \mathrm{m}$ long and $22.45 \mu \mathrm{m}$ wide. However, near the foliar base and closer to the stomatal apparatuses, the epidermal cells are mostly quadrangular, with a length and width of $21 \mu \mathrm{m}$ in mean (Plate II, 2). The periclinal walls of the epidermal cells appear granulate. Remarkably, in both abaxial and adaxial epidermis conspicuous remnants of hypodermis cells are present in the entire foliar inner surface, except near the base; making the observation of the ordinary epidermal cells difficult (Plate IV, 4).

Cuticular ultrastructure

The cuticle ultrastructure of the ordinary epidermal cells by TEM, and the subsidiary and guard cells of the stomatal apparatus are provided in detail. The hypodermis cuticle is also measured. One plate is also provided for the whole sections in the blocks of resin observed by SEM (Plate V). A theoretical cuticle consist of two parts, an outer cuticle proper $(\mathrm{CP}) \mathrm{A}$ and an inner cuticular layer $(\mathrm{CL}) \mathrm{B}$, each one divided in two layers (A1, A2, B1, B2). In the present study, four types of cuticles were observed, two for ordinary epidermal cells plus the two stomatal apparatus cells. Except for the guard cell cuticle, which is only made with B1 layer, the three other cuticles consist of an A2 granular layer (belonging to the cuticle proper) and a spongy, somewhat reticulate, B1 layer (belonging to the cuticular layer); however, in some parts of the outermost part of this B1 layer it appears more or less mixed with fine and parallel lines identical to the cell wall remnants. 

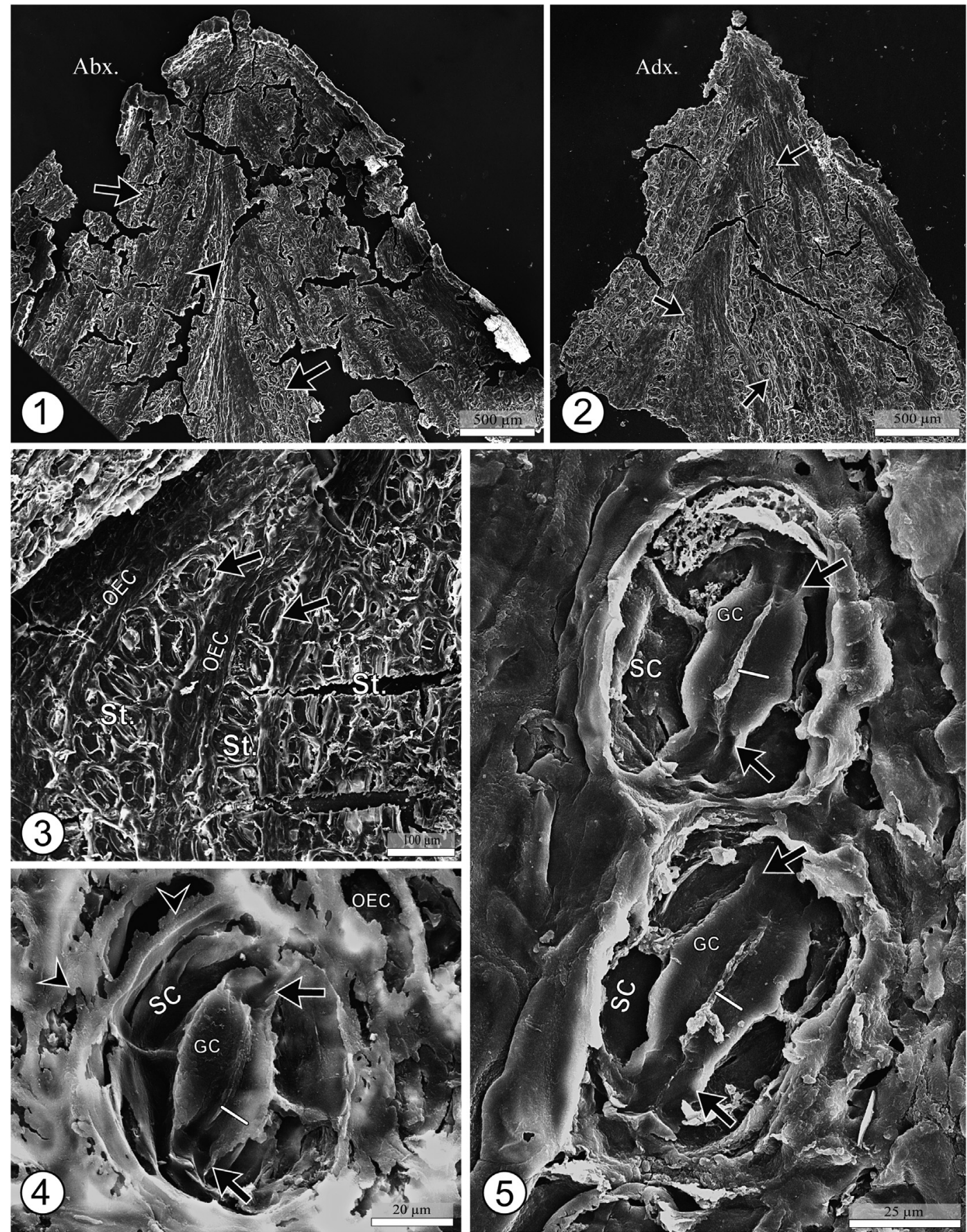

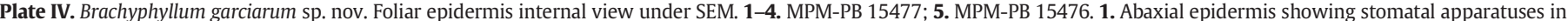

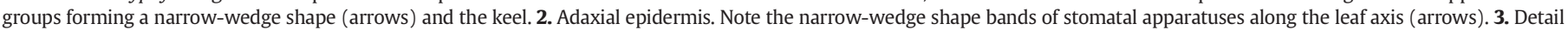

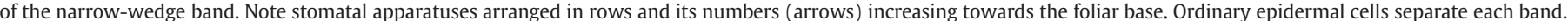

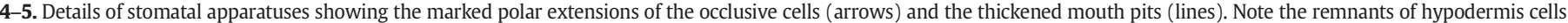
(arrowheads). Abx.: Abaxial epidermis; Adx.: Adaxial epidermis; GC: Guard cell; OEC: Ordinary epidermal cells; SC: subsidiary cells; St.: Stomatal apparatus.

Two kinds of cuticles were observed for the ordinary epidermal cell cuticle (Plates VI-IX): the upper cuticle of the leaf is the thickest with $10.12 \mu \mathrm{m}$ in mean (Table 1), with much more B1 than A2 layer $(93.8 \%$ and $6.2 \%$ in mean, respectively); the lower cuticle is the thinnest ( 8.89 $\mu \mathrm{m}$ in mean), with also more B1 than A2 layer (89.3\% and $10.7 \%$ in mean, respectively). In the details of the ultrastructure, for both upper and lower cuticles, the granular A2 layer is somewhat mixed in some cases with the fibrils of B1 layer (Plate VI, 3-5; Plate VIII, 3-6). The B1 spongy layer has various concentrations of fibrils mixed with cell wall remnants made of thin parallel lines, oriented parallel to the inner surface of the cuticle or randomly oriented, making various schemes. The bottom of the B1 layer is directly connected to cell wall remnants which are visible in many cases (Plate VI, 10-12; Plate VIII, 10-12); these wall remnants are also directly connected to cell remnants or cell locations just below. In some rare cases the cell wall even makes very complex schemes (Plate VI, 9 ) of curving lines but always in parallel groups.

The hypodermis cuticle was described in detail in the present material, although it is not much used in the interpretations of this contribution, as it is very rare material in fossil plant cuticles. The hypodermis of both the upper and lower cuticles is ultrastructurally made only with B1 spongy layer also mixed with cell wall remnants appearing as fine parallel lines (Plates VII; IX). In some well-preserved cases, parts of the 

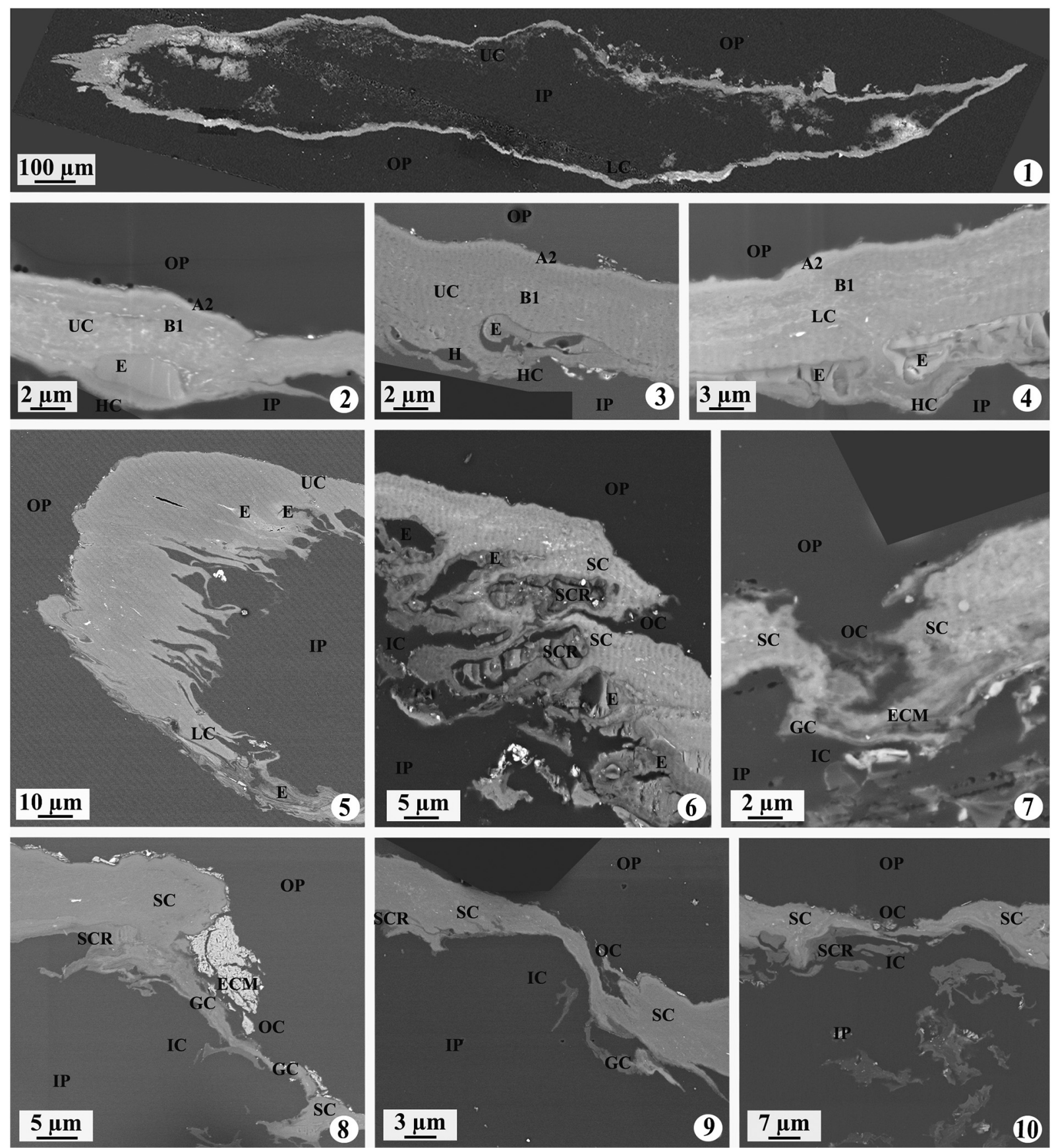

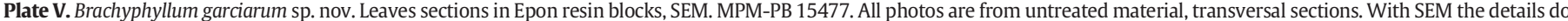

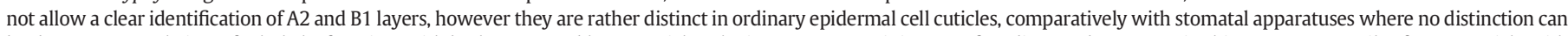

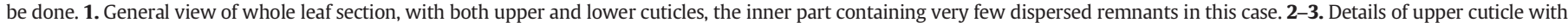

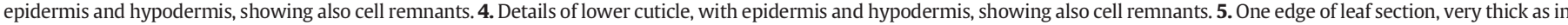

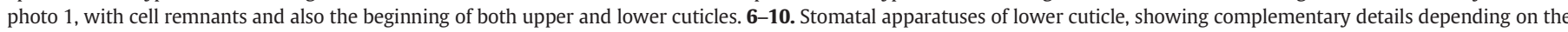

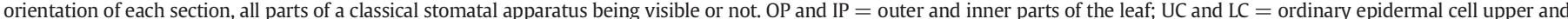

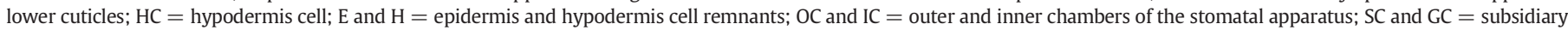
and guard cell cuticles of the stomatal apparatus; SCR and GCR = subsidiary and guard cell remnants of the stomatal apparatus.

hypodermis cells are visible in both upper and lower cuticles (Plate VII, 5, 11-13). However, in most observations, only the hypodermis upper part, which shares with the lower part of the epidermal cells, is visible (Plate VII, 6-10; Plate IX, 1-2). The hypodermis upper part is similar in thickness between the upper and lower cuticles (1.15 and $1.14 \mu \mathrm{m}$ in mean, supplementary material Appendix A). The lower part of the hypodermis that represents the lowermost part of the cuticle is rarely observed. Amorphous and darkly stained cell remnants are also present.
Regarding the stomatal apparatuses (Plates X-XI), the subsidiary cell cuticle has a thickness of $9.28 \mu \mathrm{m}$ in mean, and presents a high proportion of spongy B1 layer (87.2\%) mixed with cell wall remnants and a thin granular A2 layer (12.8\% of the total thickness). The guard cell cuticle is $1.34 \mu \mathrm{m}$ in mean, only made of B1 spongy layer mixed with cell wall remnants making parallel lines, showing the most variable concentrations of cuticle (Plate XI). Amorphous and darkly stained cell remnants are also present. 

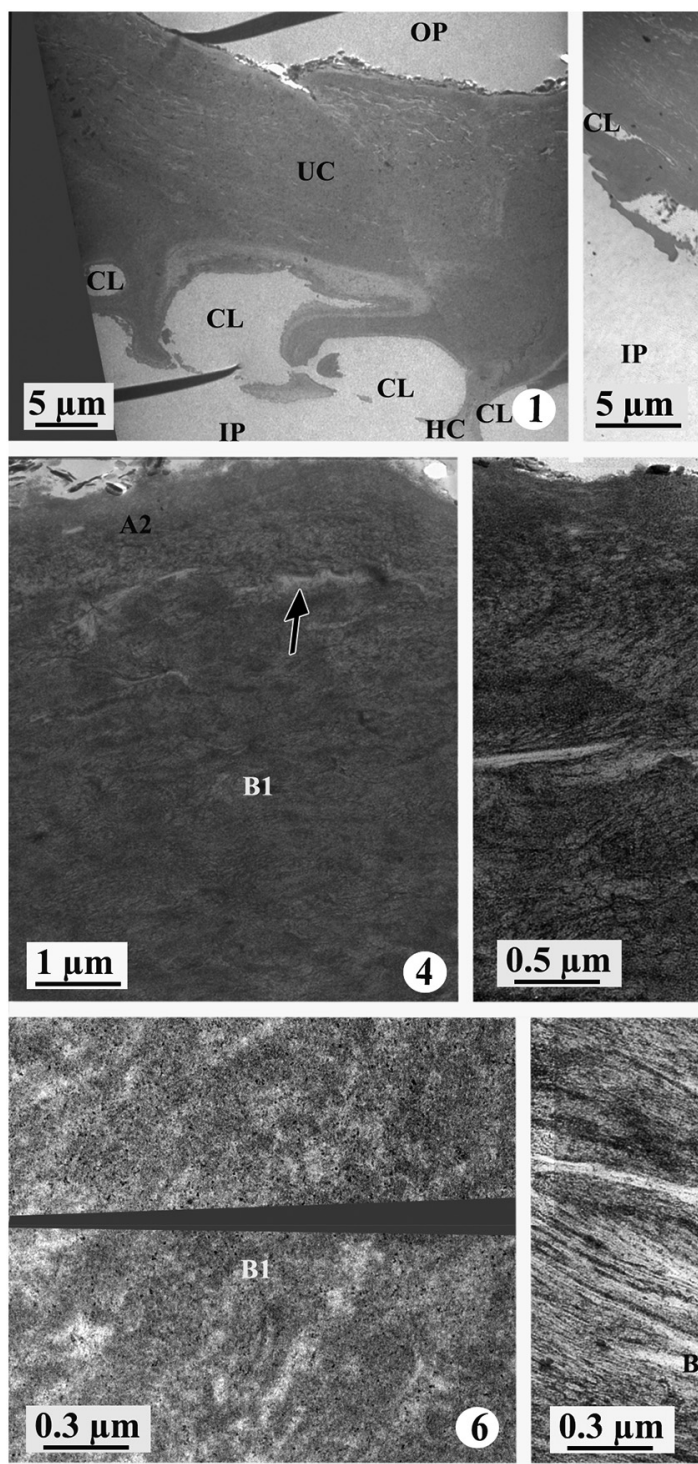

$0.5 \mu \mathrm{m}$
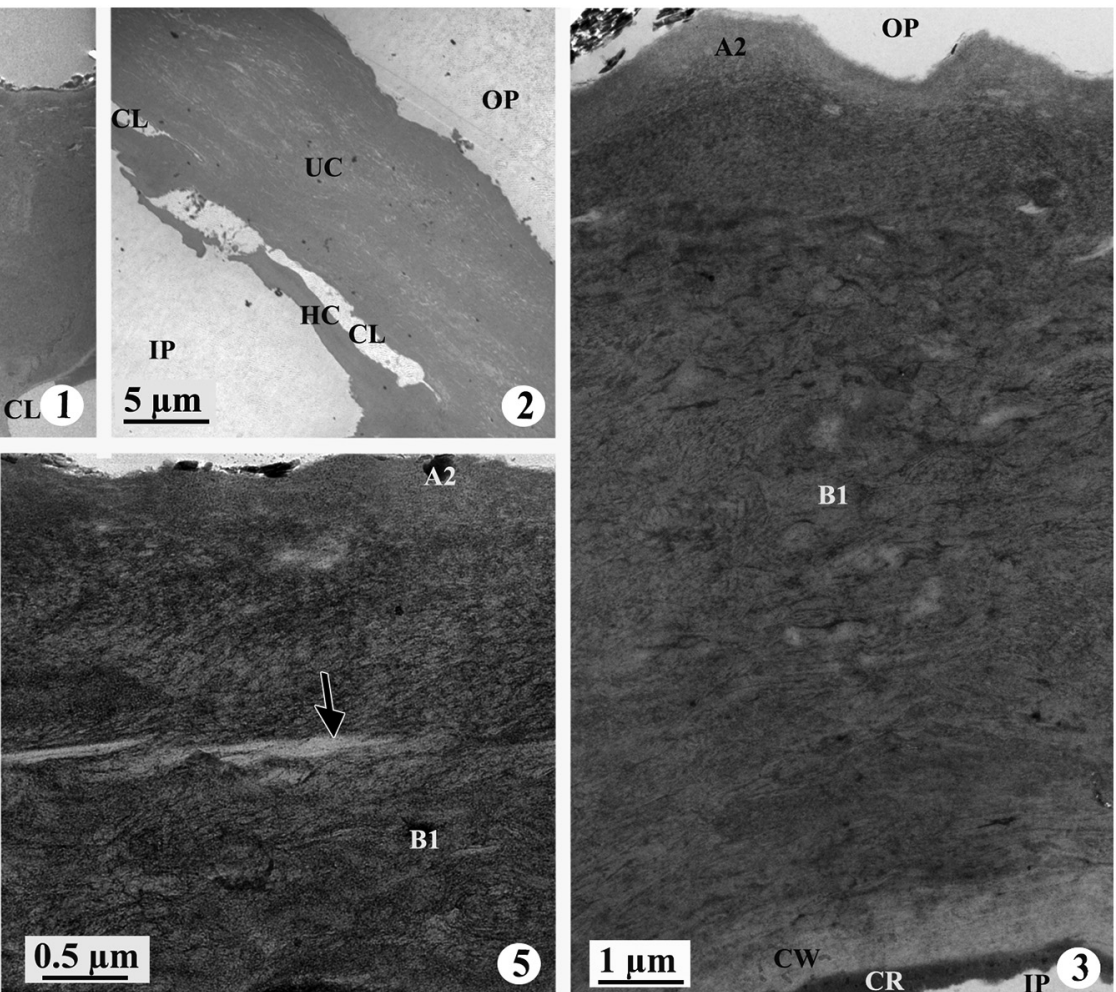

B1
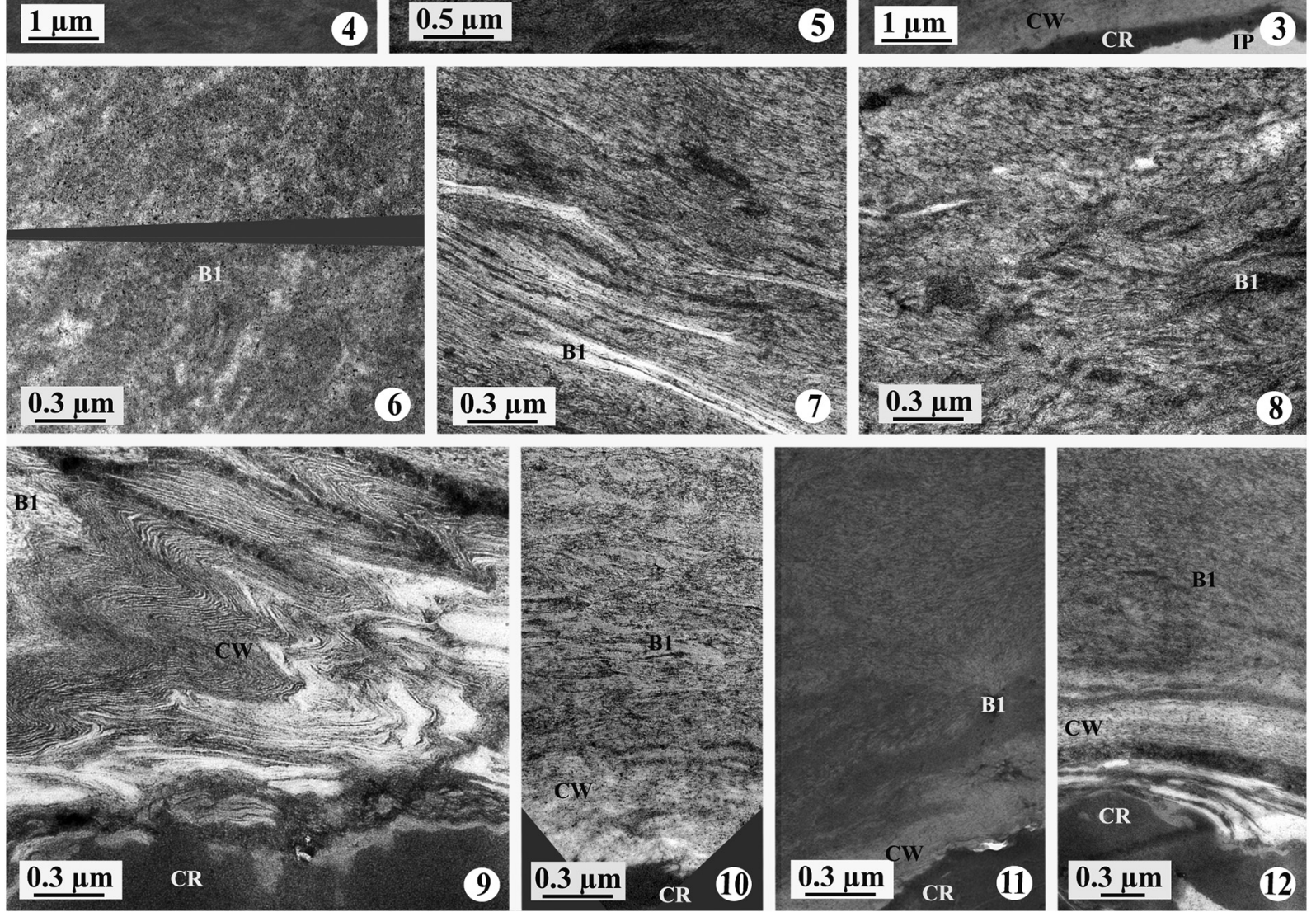

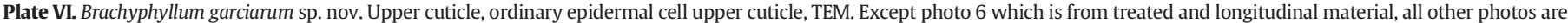

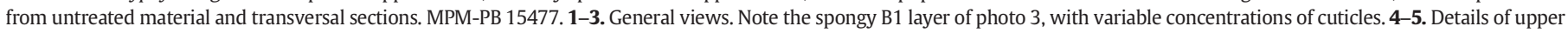

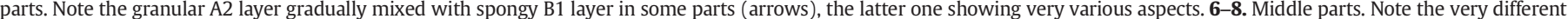

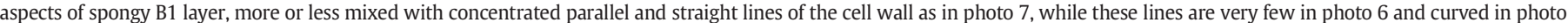

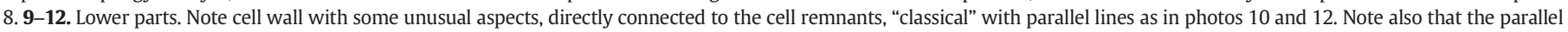

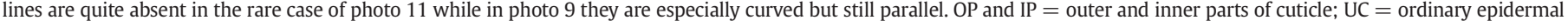
cell upper cuticle; $\mathrm{HC}=$ hypodermis cell; $\mathrm{CR}=$ cell remnants, $\mathrm{CL}=$ cell location; $\mathrm{A} 2$ and $\mathrm{B} 1=$ the two layers of this type of cuticle. 

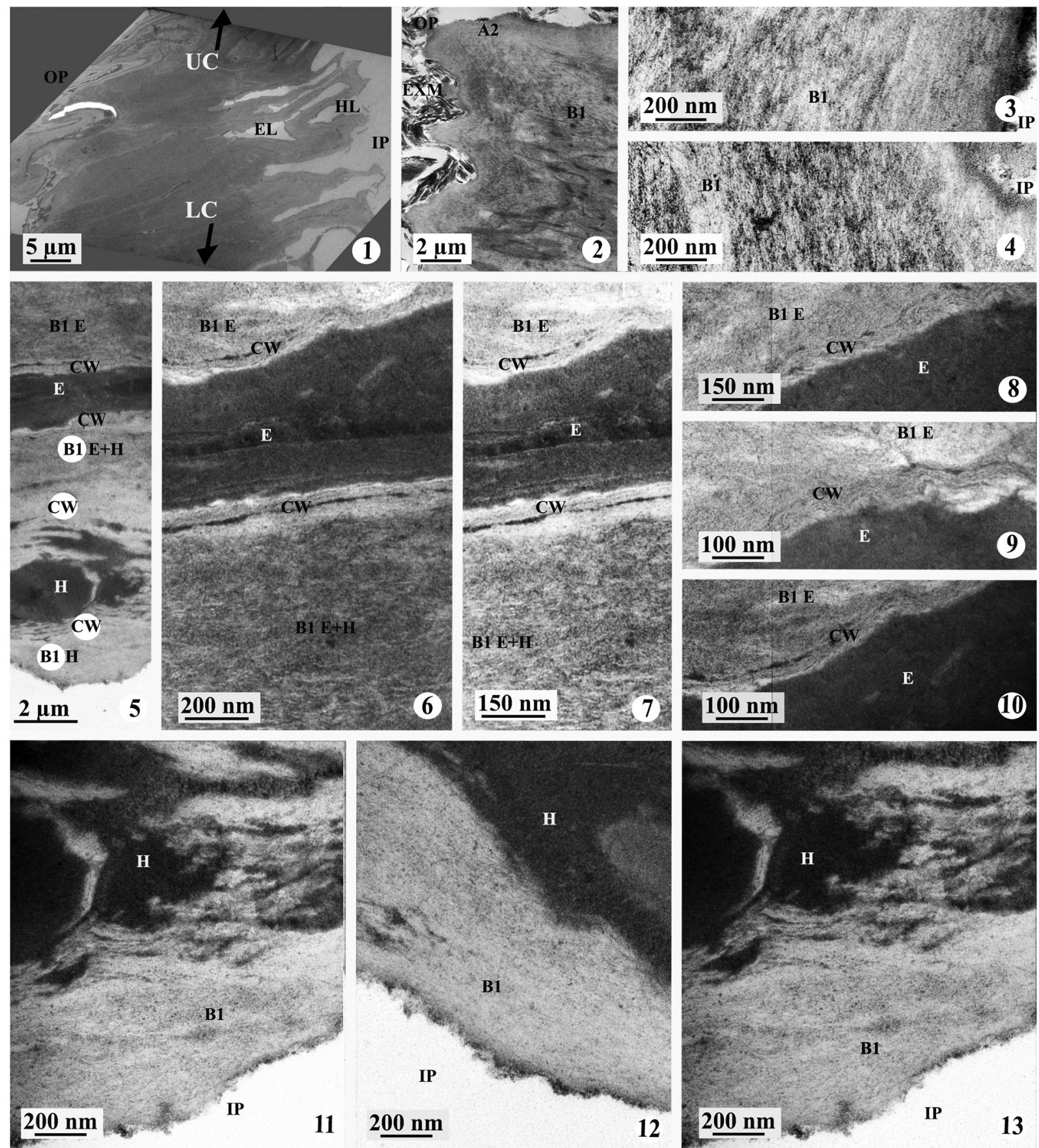

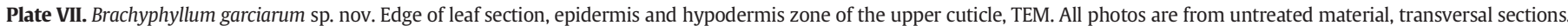

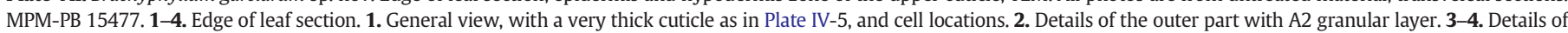

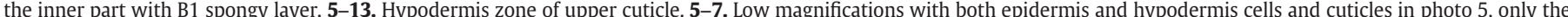

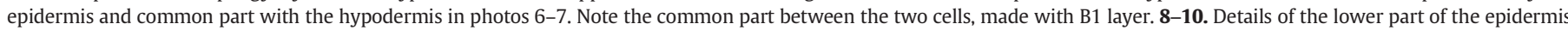

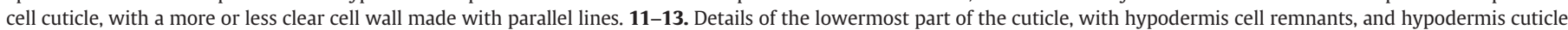

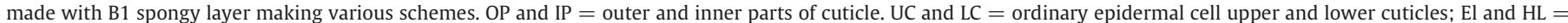

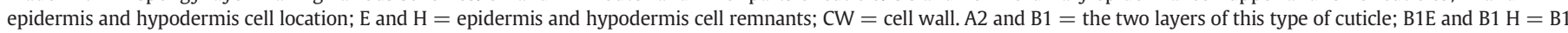
layer of the epidermis or hypodermis, $\mathrm{B} 1 \mathrm{E}+\mathrm{H}=$ common $\mathrm{B} 1$ layer to epidermis ad hypodermis cells; $\mathrm{EXM}=$ extra-cuticular material.

\subsection{EDS analysis}

Two EDS analyses were performed by TEM and SEM. Firstly, using the EDS system (Fig. 2), and because of the insignificant differences from the Mann-Whitney test for five measurements, quantitative data of the cuticle elements obtained allowed us to select 14 ratios among all possibilities: N/S, N/Cl, N/K, N/Ca, N/NA, S/Cl, S/K, S/Ca, S/ $\mathrm{Na}, \mathrm{Cl} / \mathrm{K}, \mathrm{Cl} / \mathrm{Ca}, \mathrm{Cl} / \mathrm{Na}, \mathrm{K} / \mathrm{Ca}, \mathrm{K} / \mathrm{Na}$ (Table 2 , supplementary material
Appendix B). These selected ratios concern the two layers (A2, B1), and cell wall and hypodermis of the ordinary epidermal cell lower and upper cuticles, all having homogeneous values of resin to provide similar eventual errors due to the elements in the resin, though usable for comparisons of statistical significance. Added to the confidence interval values, all of these cuticle ratios were also determined to be significantly different or not by the Mann-Whitney test (Fig. 3). Among the possibilities of comparisons (between A2 and B1, cell wall 

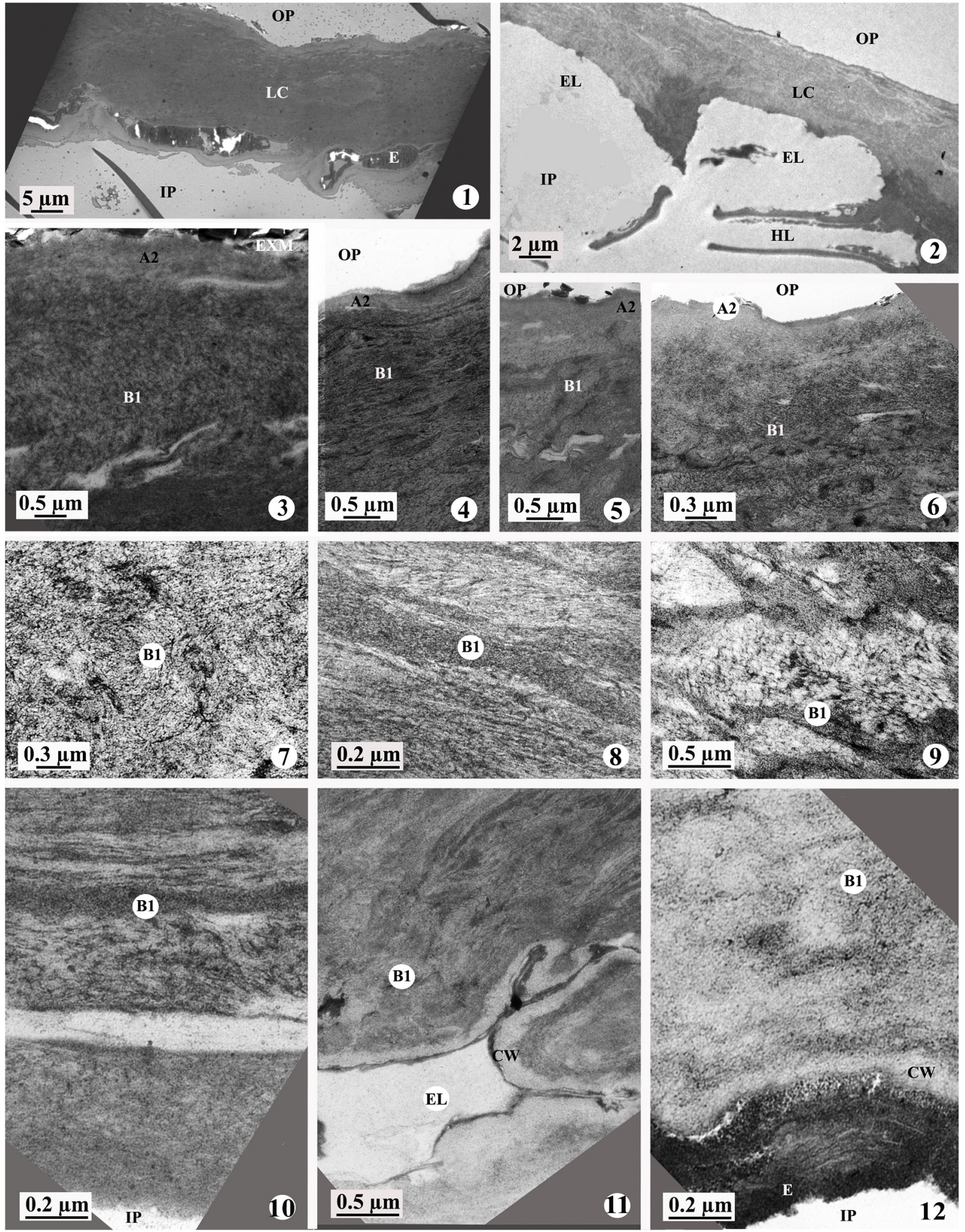

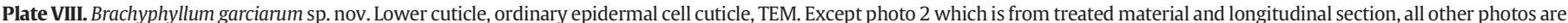

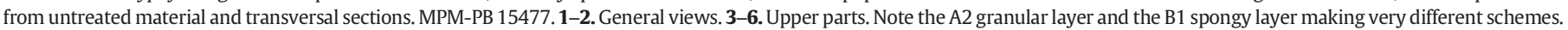

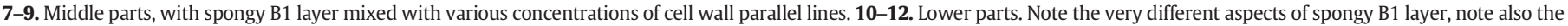

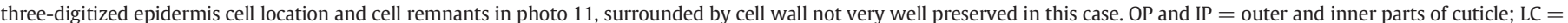

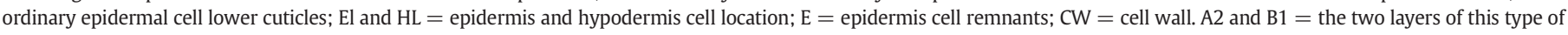
cuticle; EXM = extra-cuticular material.

and hypodermis within each type of cuticle; between A2 and B1, cell wall and hypodermis of each type of cuticle), 61 ratio means have significant differences in ratio value while 57 ratio means have insignificant differences (Table 2, Fig. 3). In the EDS analyses, the combination of these ratios makes that each layer has its own characteristics. 

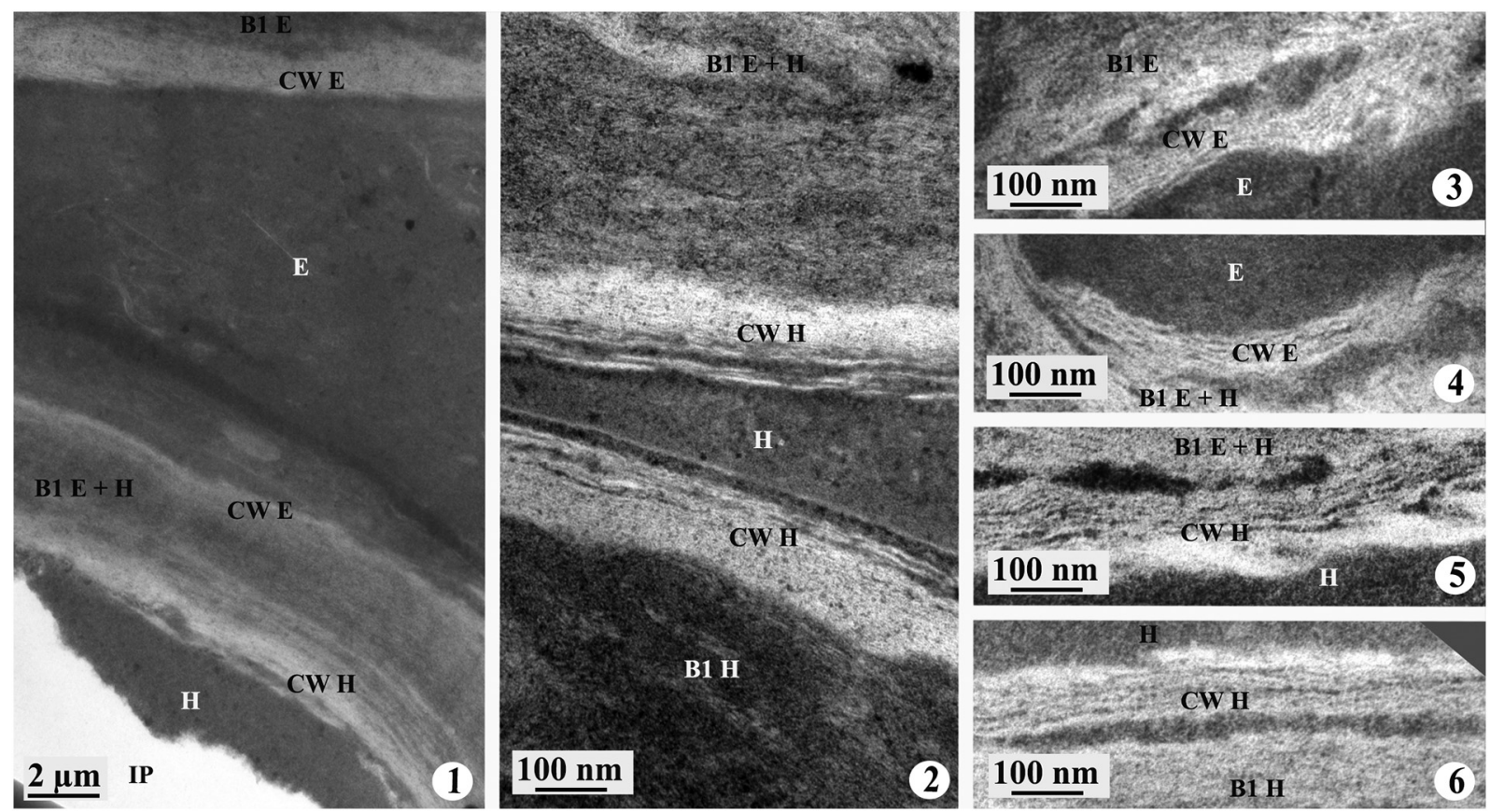

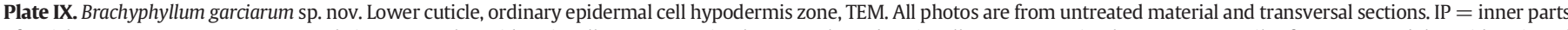

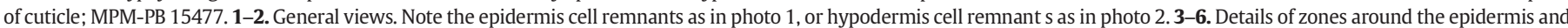

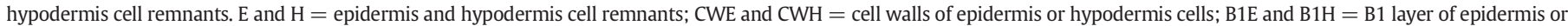
hypodermis cells; $\mathrm{B} 1 \mathrm{E}+\mathrm{H}=$ common $\mathrm{B} 1$ layer between epidermis and hypodermis cells.

Secondly, EDS by SEM provided qualitative mapping of $\mathrm{Na}, \mathrm{Al}, \mathrm{Si}, \mathrm{S}$ and Cl elements (Fig. 4). Na and S are present in the whole parts of the cuticles, while $\mathrm{Cl}$ is mainly present in the $\mathrm{A} 2$ layer and in the cell wall; this is congruent with the EDS-TEM absolute values (supplementary material Appendix $\mathrm{B}$ ). However, just for $\mathrm{Cl}$ in the lower cuticle, the value of the $\mathrm{B} 1$ layer is different, being quite high where it should instead be low. The differences may be due to the resin presence in the checks. Compared with EDS-TEM, K, Ca and N are not provided because they were not detected by the very short time of spectrum acquisition $\left(10^{-2} \mathrm{~s}\right.$, compared with $120 \mathrm{~s}$ for EDS-TEM), while their absolute values by EDS-TEM are below 1 . Moreover, the additional data concerning $\mathrm{Al}$ and $\mathrm{Si}$, were not selected by EDS-TEM, belonging potentially to the microscope procedure. They are absent from cuticles, but present in the extracuticular material.

\section{Discussion}

\subsection{Comparison with other Cretaceous species of Brachyphyllum from Western Gondwana}

The foliar epidermal features observed in Brachyphyllum garciarum sp. nov. make this taxon clearly distinguishable from other Cretaceous species of the genus from Western Gondwana (Fig. 5). Among the 10 species available for comparisons, $B$. feistmantelli has been to date, the only described species from the Springhill Formation; it differs from B. garciarum sp. nov. due to the presence of stomatal apparatuses randomly located and stomatal pits irregularly oriented. In addition, the stomatal apparatus in B. feistmantelli is monocyclic to imperfectly dicyclic unlike $B$. garciarum sp. nov. which is always monocyclic (Archangelsky, 1976; Baldoni, 1979).

The leaves of Brachyphyllum mucronatum have an adaxial epidermis only one-third of the total length of the abaxial epidermis; the stomatal apparatuses are monocyclic to imperfectly dicyclic, placed in short slightly defined rows and the subsidiary cells rarely are in contact between neighboring stomatal apparatuses. In addition, in B. mucronatum the stomatal chambers are larger $(50 \mu \mathrm{m})$ than those of $B$. garciarum sp. nov., and the subsidiary cells usually present a cuticular thickening around the mouth pit that forms the Florin's ring, characteristic not shown by B. garciarum sp. nov. (Archangelsky, 1963).

Unlike B. garciarum sp. nov., B. mirandai has bigger leaves $(0.7 \mathrm{~cm}$ long $\times 0.4 \mathrm{~cm}$ wide) and the adaxial epidermis is only one-fourth of the total length of the abaxial epidermis. The epidermal cells are larger $(50 \mu \mathrm{m})$; the stomatal apparatuses are randomly located, rarely forming slightly defined rows and the mouth pits are mostly longitudinally orientated. Stomatal apparatuses in B. mirandai are monocyclic to imperfectly dicyclic and the subsidiary cells have numerous distinct cuticular striae and granules of varying sizes which differ from B. garciarum sp. nov. (Archangelsky, 1963).

Brachyphyllum irregulare has leaves with a width to length ratio of $2: 1$ in contrast with the ratio of $1: 1$ of $B$. garciarum sp. nov. The stomatal apparatuses in the former taxa are monocyclic to imperfectly dicyclic; they are randomly placed, rarely forming slightly defined rows; and the subsidiary cells show the Florin's ring (Archangelsky, 1963).

The leaves of $B$. brettii differ from those of $B$. garciarum sp. nov. because they are narrower (1.5-1.75 mm wide), the adaxial epidermis is only one-third to one-fourth of the total length of the abaxial epidermis, and the foliar apex is rounded to acute. In addition, the stomatal apparatuses are monocyclic to imperfectly dicyclic with subsidiary cells separated by one or more ordinary cells between stomatal apparatuses, and usually with the Florin's ring. Also, the epidermis of $B$. brettii shows cuticular striations that usually dichotomize forming a reticulum, a feature not observed in B. garciarum sp. nov. (Archangelsky, 1963).

Brachyphyllum garciarum sp. nov. differs from $B$. baqueroense and $B$. kachaikensis due to these two latter taxa have thinner leaves (0.7-1.5 mm wide) with acute to slightly rounded apex and microscopically serrulate margins. Both species also present monocyclic to imperfectly dicyclic stomatal apparatuses disposed in ill-defined rows. Additionally in $B$. baqueroense, the subsidiary cells show papillae surrounding the stomatal apparatuses, whereas in B. kachaikensis the subsidiary cells present cuticular striations radially disposed to the pit mouth, characters not seen in B. garciarum sp. nov. (Traverso, 1968; Passalia, 2007).

Finally, Nothopehuen brevis (Araucariaceae), Squamastrobus tigrensis (Podocarpaceae) and Kachaikestrobus acuminatus (Cheirolepidiaceae) 

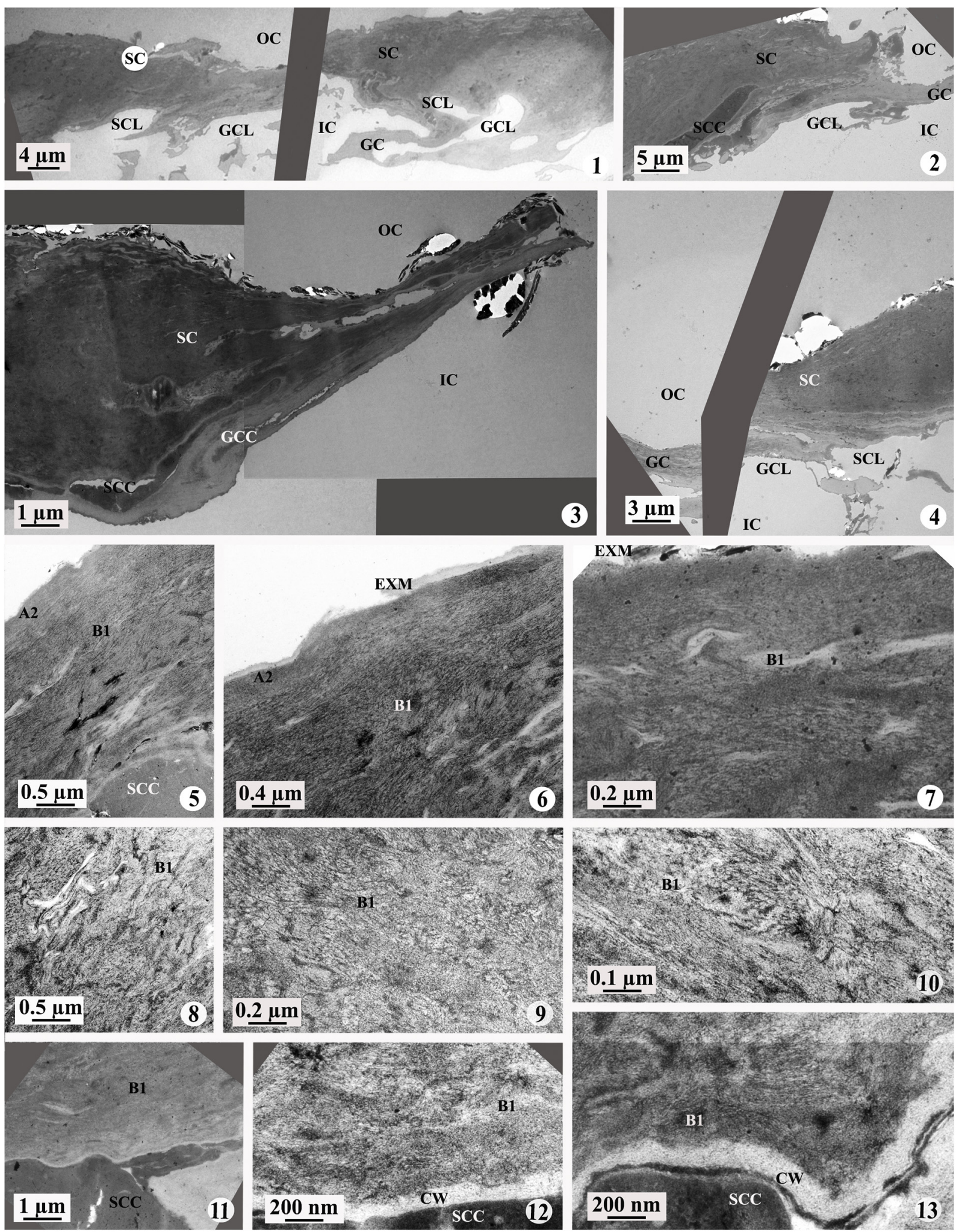

Plate X. Brachyphyllum garciarum sp. nov. Stomatal apparatuses and details of subsidiary cell lower cuticles, TEM. All photos are from untreated material and transversal sections. MPM-PB 15477. 1-4. General views of entire or half stomatal apparatuses. 5-13. Details of subsidiary cell cuticles. 5-7. Upper parts, note the A2 layer, not present in the rare case of photo 7 , somewhat mixed with the subjacent B1 spongy layer, the latter one making very different schemes and mixed with parallel lines of the cell wall. 8-10. Middle parts, note the B1 spongy layer with various concentrations of cuticle and parallel lines of cell wall. 11-13. Lower parts, in connection with the subsidiary cell remnants in the lowermost parts of the photos. The parallel lines of the cell wall are quite distinct or invisible in some parts, very present in B1 layer as in the right side of photo 13 . OC and IC $=$ outer and inner chambers of stomatal apparatus; SC and GC = subsidiary and guard cell cuticles; ECC and HCC = ordinary epidermal and hypodermal cell remnants; SCC and GCC = subsidiary and guard cell remnants; SCL and GCL = subsidiary and guard cell locations. A2 and B1 = the two layers of this type of cuticle. CW = cell wall. EXM = extra-cuticular material. 

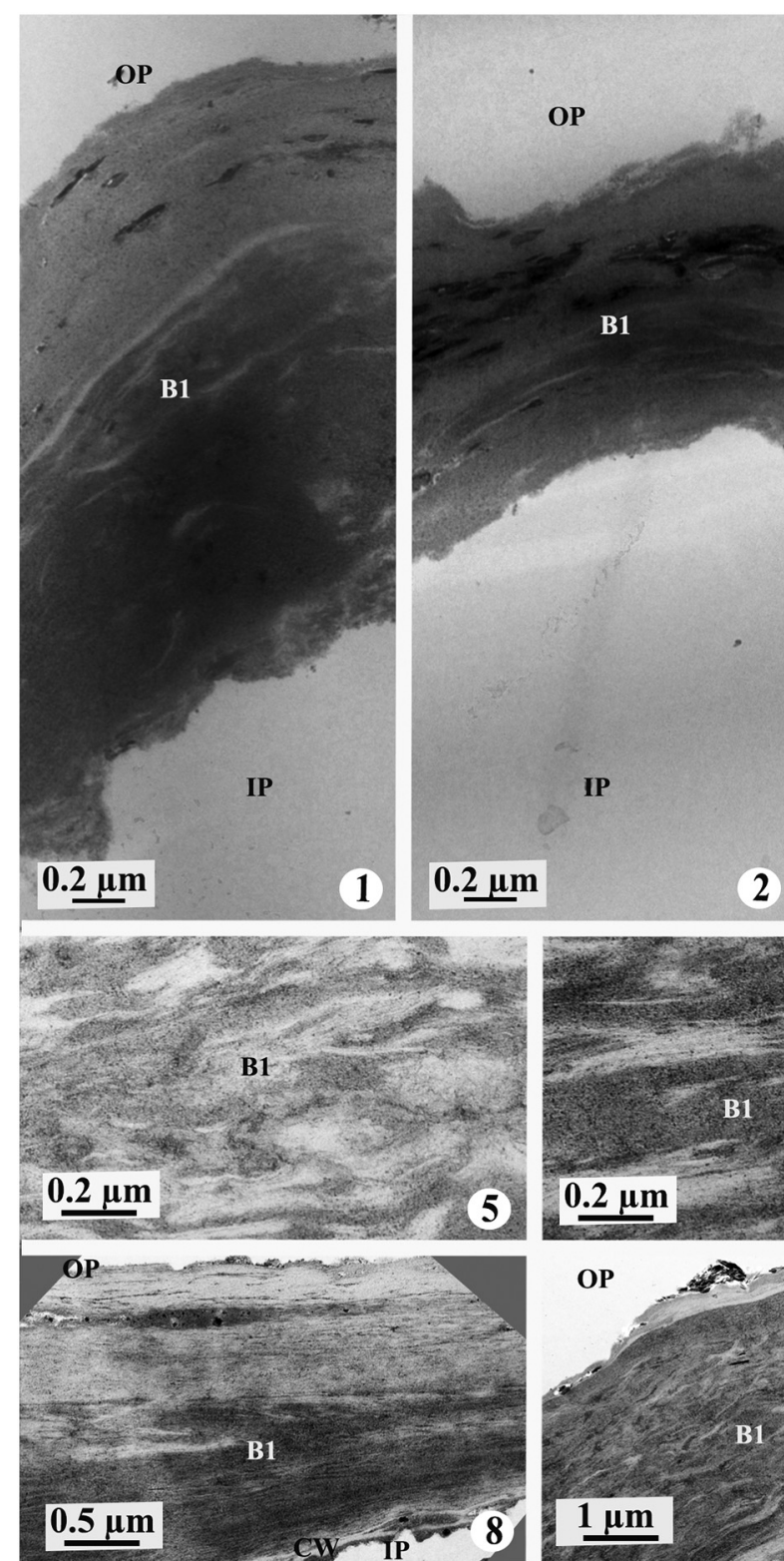

\section{$5.0 .2 \mu \mathrm{m}$}
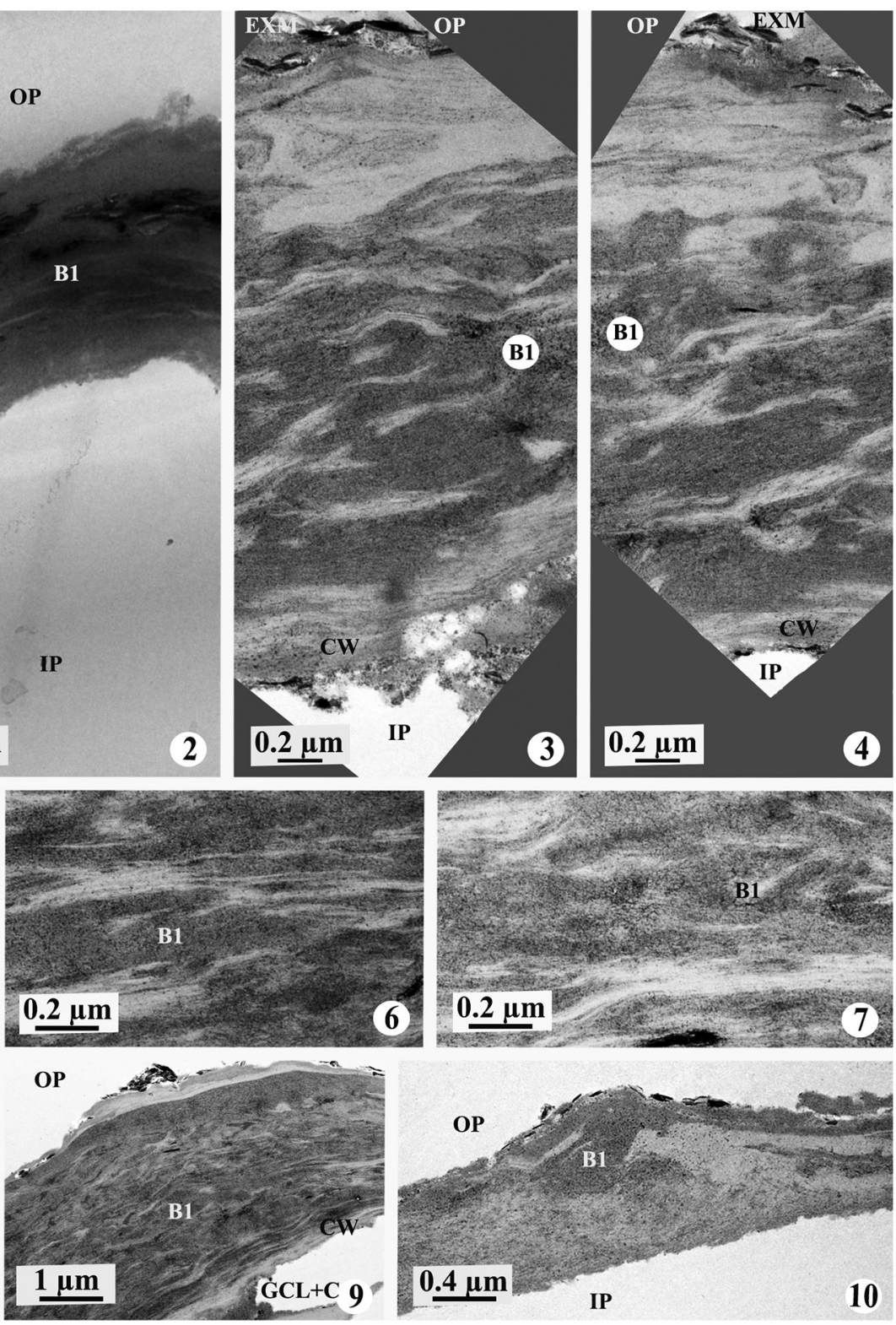

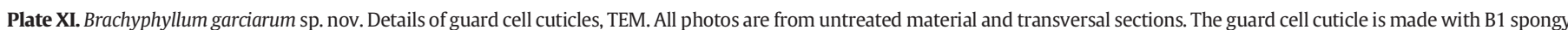

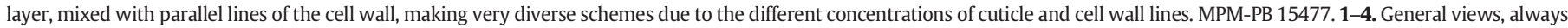

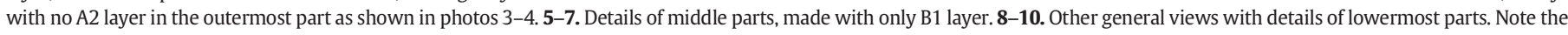
cell wall, absent in the rare case of photo 10 . OP and IP = outer and inner parts of cuticle; CW = cell wall; GCL $+\mathrm{C}=$ guard cell location and remnants.

are three Cretaceous conifer taxa from Patagonia that were found with pollen and ovulate cones in organic connection to twigs with leaves of the Brachyphyllum type. The leaves of $N$. brevis differ from those of $B$. garciarum sp. nov. in that the former have smaller leaves $(2.14 \mathrm{~mm}$ long $\times 1.1 \mathrm{~mm}$ wide) with serrulate margin, abundant papillae in both epidermis, and stomatal apparatuses disposed in slightly defined rows. In S. tigrensis the leaves have a width to length ratio of $2: 1$ in contrast with the ratio of $1: 1$ of $B$. garciarum sp. nov. Additionally, S. tigrensis also differs from $B$. garciarum sp. nov. by the presence of a serrate foliar margin, a higher stomatal density $\left(\sim 100 \times \mathrm{mm}^{2}\right)$, and because it has the Florin's ring. In the case of $K$. acuminatus, it differs from $B$. garciarum sp. nov. because their leaves are more elongate (3.6-4 mm long $\times 2 \mathrm{~mm}$ wide) and with margins irregularly serrate. Also both leaf surfaces present papillae; the stomatal apparatuses are randomly located with a lower density (4-12 per $\mathrm{mm}^{2}$ ); and have the Florin's ring (Traverso, 1966; Archangelsky and Del Fueyo, 1989; Del Fueyo, 1991; Del Fueyo et al., 2008).
The adpressed scale-like leaves spirally disposed on the fossils twigs herein studied find its systematic assignment within the genus Brachyphyllum Harris. Whereas the combination of morphological and epidermal features shown by the specimens, such as the rhomboidal to pyramidal foliar shape, the leaf size with a ratio of 1:1 and the stomatal apparatuses disposed in up to 11 narrow-wedge shape bands, are clearly distinguishable from other contemporary species of the genus described for the Cretaceous of Western Gondwana, which allow the erection of a new taxon, Brachyphyllum garciarum sp. nov.

\subsection{Taxonomy and fine details of cuticle ultrastructure}

Statistical analyses allowed comparisons between layers using confidence intervals (Fig. 6). Among the three evaluated characters (total CM thickness, A2 and B1 layers), three types of cuticles are thicker and very homogeneous (the ordinary epidermal cell upper and lower cuticles, and the subsidiary cell cuticle of the lower cuticle) with a mean 
Table 1

Statistical values of ultrastructural fine details, made with 30 measurements for each type of cell cuticles.

\begin{tabular}{|c|c|c|c|c|c|c|c|c|}
\hline \multicolumn{5}{|c|}{ Ordinary epidermal cell, upper cuticle } & \multicolumn{4}{|c|}{$\begin{array}{l}\text { Ordinary epidermal cell, lower } \\
\text { cuticle }\end{array}$} \\
\hline & Mean & Min-max & $\%$ & St-d & Mean & Min-max & $\%$ & St-d \\
\hline $\mathrm{CM}$ & 10.12 & $6.31-20.60$ & 100 & 3.78 & 8.89 & $3.23-16.36$ & 100 & 3.51 \\
\hline $\begin{array}{l}\mathrm{CP}(\mathrm{A}) \\
\mathrm{A} 2\end{array}$ & 0.62 & $0.18-1.59$ & 6.2 & 0.36 & 0.95 & $0.37-2.96$ & 10.7 & 0.58 \\
\hline $\begin{array}{l}\mathrm{CL}(\mathrm{B}) \\
\mathrm{B} 1\end{array}$ & 9.49 & $5.80-19.26$ & 93.8 & 3.47 & 7.94 & $2.81-15.49$ & 89.3 & 3.30 \\
\hline \multicolumn{5}{|c|}{ Hypodermis cell, upper cuticle } & \multicolumn{4}{|c|}{ Hypodermis cell, lower cuticle } \\
\hline & Mean & Min-max & $\%$ & St-d & Mean & Min-max & $\%$ & St-d \\
\hline $\begin{array}{l}\mathrm{CL}(\mathrm{B}) \\
\mathrm{B} 1\end{array}$ & 1.15 & $0.68-2.80$ & 100 & 0.56 & 1.14 & $0.20-2.83$ & & 0.76 \\
\hline \multicolumn{9}{|c|}{ Stomatal apparatus } \\
\hline & Mean & Min-max & $\%$ & St-d & Mean & Min-max & $\%$ & St-d \\
\hline $\mathrm{CM}$ & 9.28 & $4.06-14.13$ & 100 & 2.43 & 1.34 & $0.70-1.94$ & 100 & 0.33 \\
\hline $\begin{array}{l}\mathrm{CP}(\mathrm{A}) \\
\mathrm{A} 2\end{array}$ & 1.19 & $0.49-2.05$ & 12.8 & 0.44 & & & & \\
\hline $\begin{array}{c}\mathrm{CL}(\mathrm{B}) \\
\mathrm{B} 1\end{array}$ & 8.09 & $3.36-12.39$ & 87.2 & 2.33 & 1.34 & $0.70-1.94$ & 100 & 0.33 \\
\hline
\end{tabular}

Note. Min-max = minimum and maximum values observed. $\%=$ percentage of each detailed part of the cuticle. St-d = standard deviation. The cuticular membrane CM is made up with cuticle proper $\mathrm{CP}$ ( $=\mathrm{A}=\mathrm{A} 2$ layer) and cuticular layer $\mathrm{CL}$ ( $=\mathrm{B}=\mathrm{B} 1$ layer). All other measurements are in $\mu \mathrm{m}$.

of $8.89-10.12 \mu \mathrm{m}$, made of a thin A2 layer (6.2-12.8\% of the total CM) and a thick B1 layer (87.2-93.8\% of the total thickness). On the contrary, the guard cell cuticle is very thin ( $1.34 \mu \mathrm{m}$ in mean) and made only of $100 \%$ of B1 layer. Because of the very good quality of preservation, a threedimensional reconstruction (Fig. 7) and a dichotomous key (Table 2) were made. In Table 2, using very simple keys, i.e. the presence or absence of A2 layer, the thickness of A2 layer and the total CM and B1 layer thicknesses, the four types of cuticles are easily identified. As it is the first detailed study of Brachyphyllum garciarum sp. nov., it can be considered as the first ultrastructural reference, at least at the species level.

Considering the comparison of the cuticular layers made of A2 and $\mathrm{B} 1$ at a higher taxonomy level, genus or family, it is revealed that in the Baiera-Sphenobaiera (Ginkgoales) cuticle group these layers are remarkably different from those observed in Brachyphyllum garciarum sp. nov. In the Ginkgoales cuticles, the B1 layer is fibrilous and devoid of cell wall remnants if compared with the spongy B1 layer mixed with cell wall remnants of $B$. garciarum sp. nov. (Wang et al., 2005: Guignard et al., 2019).

Conversely, in the Araucariaceae (Coniferales), the foliar cuticles in both Nothopehuen brevis (Del Fueyo, 1991) and Araucaria grandifolia (Del Fueyo and Archangelsky, 2002) are remarkably similar to those of Brachyphyllum garciarum sp. nov. Both araucarian cuticles show a thick middle part which is almost identical with the very heterogeneous spongy B1 layer of B. garciarum sp. nov. In addition, the homogeneouslamellate outer layer of $N$. brevis and A. grandifolia could be very analogous to the thin A2 layer of $B$. garciarum sp. nov., although this A2 layer in this taxon is granular but somewhat mixed with some fibrils of the B1 layer (see Plate VI 4,5 and Plate VIII 3,6 for ordinary epidermal cell cuticle; Plate X 5,7 for subsidiary cell cuticle). Moreover, the inner layer in $N$. brevis (Del Fueyo, 1991), described as homogeneous although parallel lines are not visible due to the low enlargements, can be interpreted as the cell wall remnants of $B$. garciarum sp. nov. Therefore, the presence of the granular A2 layer and the spongy B1 layer mixed with cell wall remnants seems to be potentially relevant at the family level. However, due to the lack of detailed statistical measurements between genus and/ or species it is not possible at the moment to use those cuticular details as accurate taxonomic tools.

In addition, although to a certain extent some proportions of the layers and/or sublayers of cuticle's ultrastruture are related with the environement, in the rare studies where it could be checked (fossil Suturovagina intermedia from two localities, Yang et al., 2018; living Pinus halepensis and Erica arborea from two localities, Bartiromo et al., 2012,2013 ) the presence/absence of the layers is a constant feature and provides a unique combination for each taxon. This stability of characters is also true with the increasing number of fossil cuticles studied belonging to several other fossil families and orders (Guignard, 2019). In Brachyphyllum garciarum sp. nov. ultrastructure features are not identical to those present in other fossil families and orders such as: other Coniferales (Cheirolepidiaceae, Guignard et al., 1998, Yang et al., 2009, Guignard et al., 2017, Yang et al., 2018; fossil Miroviaceae, Nosova et al., 2016; living Pinaceae, Bartiromo et al., 2012); Ginkgoales (Baiera-Sphenobaiera cuticle group of Ginkgoales above mentioned; Wang et al., 2005, Guignard et al., 2019; Ginkgo-GinkgoitesPseudotorellia group; Guignard and Zhou, 2005; Del Fueyo et al., 2006, Del Fueyo et al., 2013; Guignard et al., 2016, Nosova et al., 2019); Czekanowskiales (Zhou and Guignard, 1998); Pteridospermales (Guignard et al., 2001; Thévenard et al., 2005; Carrizo et al., 2014) including Corystospermaceae (Guignard et al., 2004); Bennettitales (Villar de Seoane, 1999, 2001, 2003); cycadalean cuticles (Archangelsky et al., 1995; Artabe et al., 1991; Passalia et al., 2010).

Because of the good quality of preservation of the Brachyphyllum garciarum sp. nov., an interesting aspect concerns to the GC cuticle as it is the thinnest of the other types of cuticles revealed in this taxon, with $1.34 \mu \mathrm{m}$ in mean versus the OEC cuticles with $8.89-10.12 \mu \mathrm{m}$ in mean (Table 1 ). This is congruent with previous researches and usually observed in other taxa, except for Ginkgo (living G. biloba male and female, fossil G. yimaensis), where it is the opposite: the guard cell cuticle is thicker than all lower cuticles (Guignard and Zhou, 2005). Besides the thickness, although the number of data is still too small to have some general ideas, the ultrastructural layers composition of the guard cell cuticles known so far reveals that it may be a potential precise taxonomical character at the Family-Order level. The GC cuticle of Brachyphyllum garciarum sp. nov. (Coniferales, Araucariaceae) is made of B1 layer; all Cheirolepidiaceae (Coniferales) are made of A1-A2 layers (Guignard et al., 1998; Yang et al., 2009, 2018; Guignard et al., 2017); Dichopteris (Pteridospermales; Thevenard et al., 2005) is made of A2-B1-B2 layers; and Pachypteris (Pteridospermales Corystospermaceae; Guignard et al., 2004) is made of A1-A2-B1. Moreover, the Gingkoales can be divided in two groups: the Sphenobaiera-Baiera group with GC cuticles (Wang et al., 2005; Guignard et al., 2019) made of A2-B1 layers, while the Ginkgo-Ginkgoites group has GC cuticles made of A1U-A1L-A2-B1 layers and sublayers (Guignard and Zhou, 2005). Besides its taxonomical interest, the GC cuticle being different from the other cuticles (OEC and SC) in each taxon, is correlated with the function of closing and opening the stomata, where a thin cuticle is more malleable than a thick one and its ultrastructural composition seems to reveal some particular equilibrium in each Family-Order.

\subsection{Relationship of Brachyphyllum garciarum sp. nov with extant araucarian taxa}

The foliar cuticle ultrastructure observed in Brachyphyllum garciarum sp. nov. suggests an affinity with the Araucariaceae. Additionally, the combination of morphological and cuticular features of this new species reveals a certain resemblance with extant taxa of the Araucariaceae family, especially within the genus Araucaria. Of the four recognized sections among the living species of Araucaria: Eutacta, Araucaria, Intermedia and Bunya (Wilde and Eames, 1952), the leaves of B. garciarum sp. nov. are mostly similar to those of the Eutacta section. The leaves of the other three sections can easily differentiate from those of B. garciarum by their larger size (9-120 mm long and 6-20 mm wide) and by their lanceolate-elongated and thinner form. Of the 15 species of the Eutacta section studied by Stockey and Ko (1986), 10 of them have linear-lanceolate leaves, and only 5 of them have scale-like leaves similar to $B$. garciarum sp. nov. Of these five 


\section{a. upper cuticle}

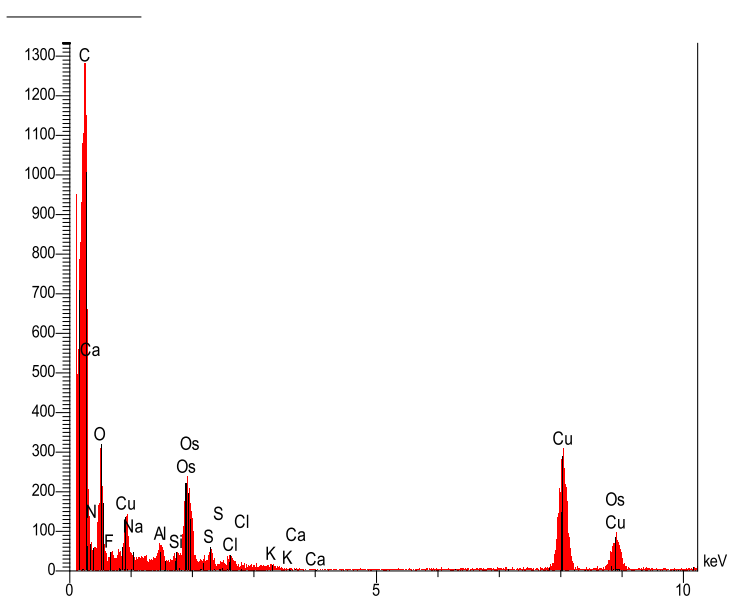

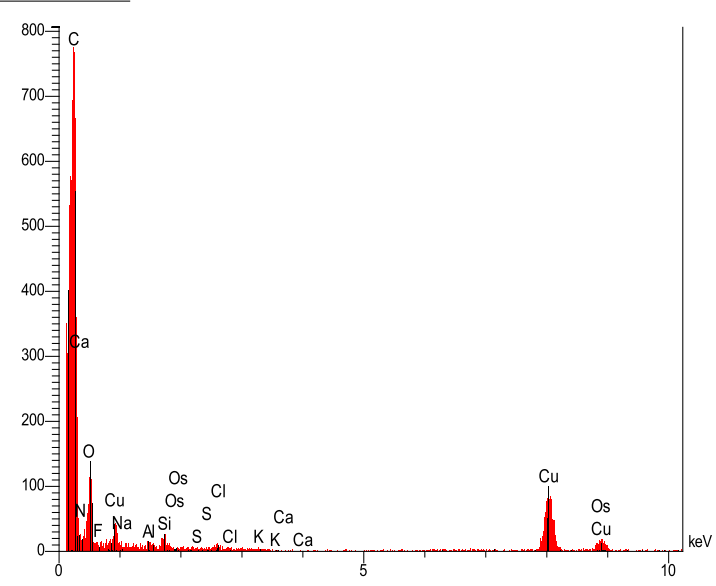

\section{b. lower cuticle}
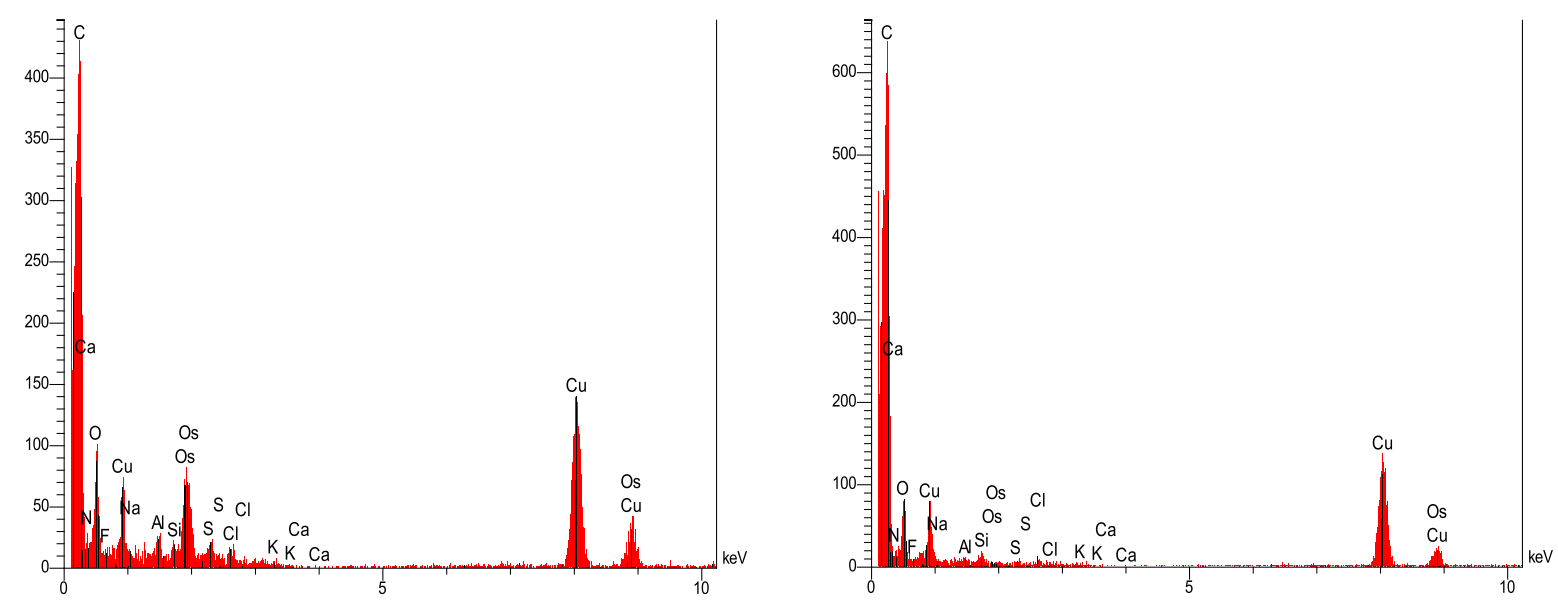

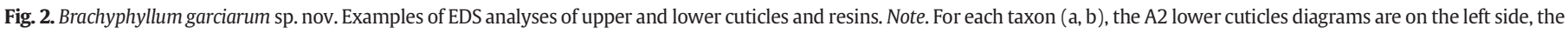
resin diagrams on the right side.

taxa, Araucaria columnaris and A. humboldtensis have bigger leaves (4-7 mm long $\times 2-5 \mathrm{~mm}$ wide) and the latter presents discontinuous rows of stomatal apparatuses in contrast to the narrow-wedge bands of $B$. garciarum sp. nov.; A. muelleri and A. rulei also have bigger leaves (15-35 mm long $\times 7-20 \mathrm{~mm}$ wide) and are somewhat more lanceolate than those of $B$. garciarum sp. nov. The juvenile leaves of $A$. scopulorum are of similar sizes as those of $B$. garciarum sp. nov. although the adult leaves get longer and become linear-lanceolate; also the stomatal apparatuses in A. scopulorum are placed in closely spaced discontinuous rows in the adaxial cuticle and in more widely spaced rows in the abaxial cuticle but without resembling the narrow-wedge bands observed in B. garciarum sp. nov.

It is also worth noting that $B$. garciarum sp. nov. shares the presence of marked polar extensions in the guard cells with all the species of
Araucaria. However, in this last taxon the number of subsidiary cells is lower, mostly four to five, very rarely six; and the ordinary epidermal cells are mostly rectangular with dimensions of 33-162 mm long $\times$ 5-15 mm wide (Stockey and Ko, 1986).

\subsection{Taxonomy and fine details of EDS}

The study of the diagenetic processes and its effect in organic fossils preservations have been carried out by several authors through simulations and experimental taphonomy explorations embracing biological (microbial/autolytic decay; e.g., Odin et al., 2018) and physicogeochemical (molecular stability through thermal maturation; e.g., Gupta et al., 2007a; González Arismendi et al., 2018; Saitta et al., 2019) alterations. These studies in plant fossils are limited due to the

Table 2

Dichotomous key of the four ultrastructural types of cuticles of Brachyphyllum garciarum sp. nov.

\begin{tabular}{|c|c|c|c|c|}
\hline \multirow[t]{3}{*}{ A2 layer and B1 layer } & A2 mean $0.62 \mu \mathrm{m}$ & Total CM mean $10.12 \mu \mathrm{m}$, B1 mean $9.49 \mu \mathrm{m}$ & Ordinary epidermal cell & Upper cuticle \\
\hline & A2 mean $0.95-1.19 \mu \mathrm{m}$ & Total CM mean $8.89 \mu \mathrm{m}, \mathrm{B} 1$ mean $7.94 \mu \mathrm{m}$ & & Lower cuticle \\
\hline & & $\begin{array}{l}\text { Total CM mean } 9.28 \mu \mathrm{m}, \mathrm{B} 1 \text { mean } 8.09 \mu \mathrm{m} \\
\text { Total CM mean } 1.34 \mu \mathrm{m}=\mathrm{B} 1 \text { layer mean }\end{array}$ & Stomatal apparatus & $\begin{array}{l}\text { Subsidiary cell cuticle } \\
\text { Guard cell cuticle }\end{array}$ \\
\hline
\end{tabular}

Note. $\mathrm{CM}=$ cuticlular membrane, made with A2 layer of the cuticle proper and B1 layer of the cuticular layer. 
a. differences/ or not between each zone of the two cuticles
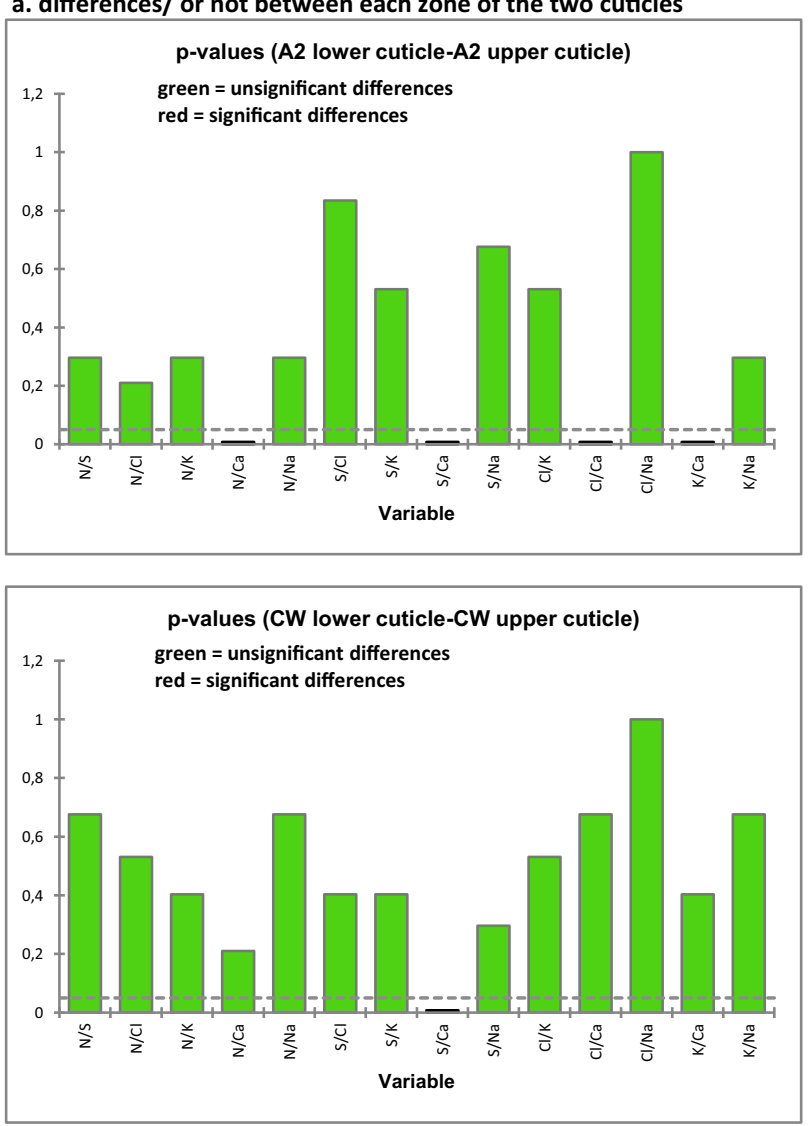

b. differences /or not between the zones of upper cuticle
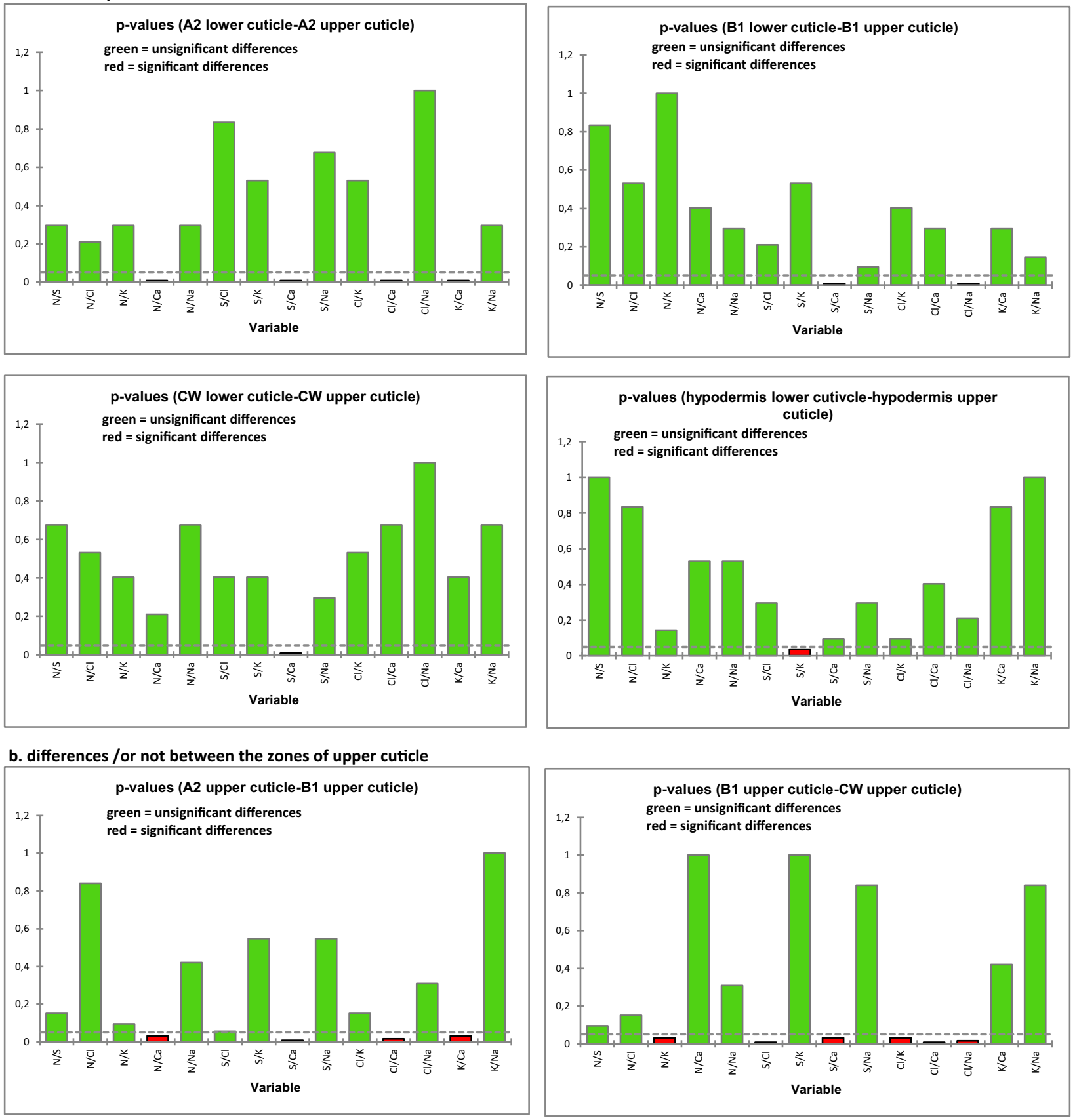

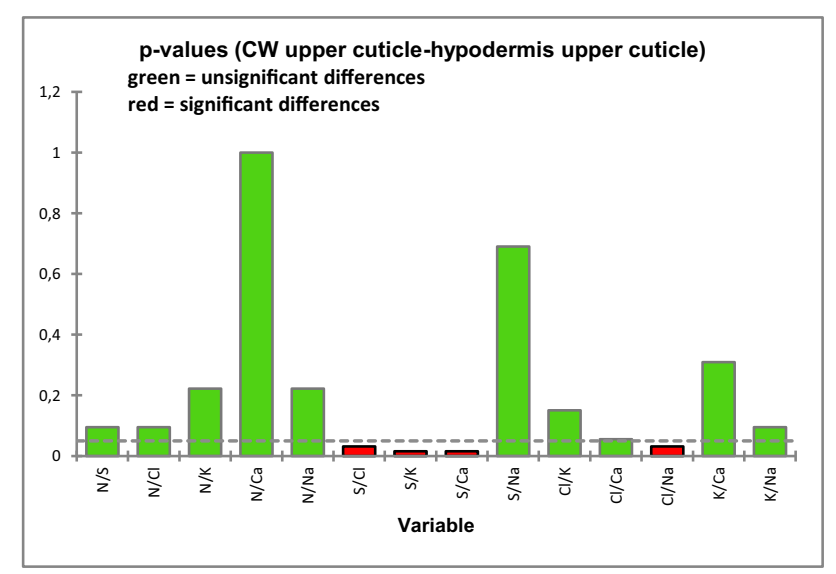

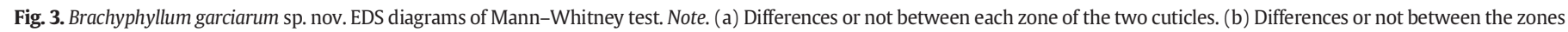
of upper cuticle. (c) Differences or not between the zones of lower cuticle. 

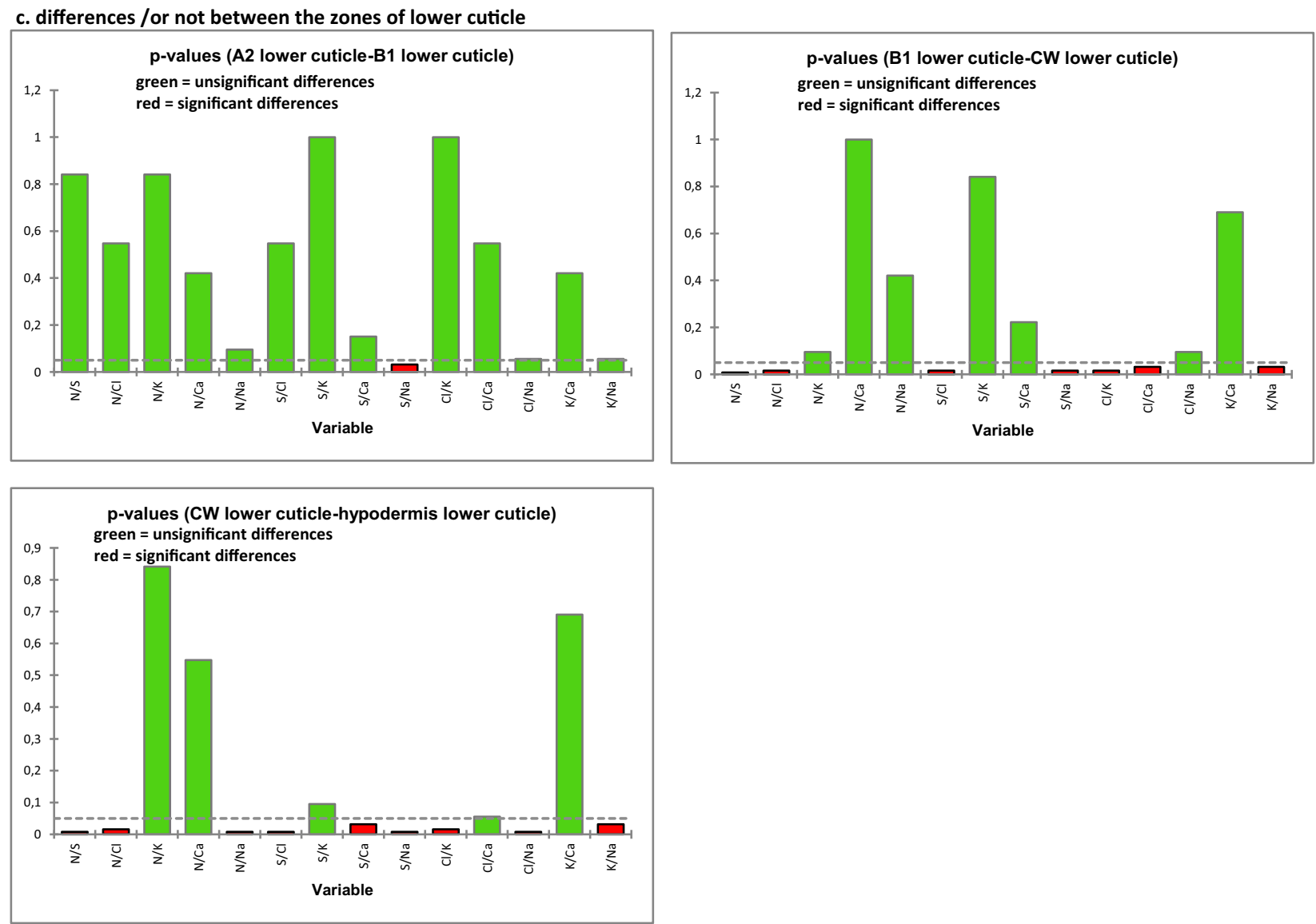

Fig. 3 (continued).

complexity of the process itself and the difficulty of its simulation (e.g., Finch and Freeman, 2001; Gupta et al., 2007a,b; Simoneit et al., 2016). Diagenesis and related studies regarding chemical composition are discussed in fossil plants, especially for functional groups (Zodrow et al., 2009, 2016, 2017; Lafuente Diaz et al., 2018; among others) as well as saccharides occurrence (Marynowski et al., 2018). However, to the best of our knowledge, the information of chemical elements such as $\mathrm{N}, \mathrm{S}, \mathrm{Cl}, \mathrm{K}$, and $\mathrm{Ca}$ (EDS analysis) concerning diagenesis in the cuticle structure is poorly known. These chemical elements probably suffered minor changes during the diagenetic processes when compare with those of complex organic molecules. In particular, the diagenesis underwent by Brachyphyllum garciarum sp. nov. and its effect on the preserved chemistry is here considered and addressed by EDS analysis. The latter would probably reflect the original chemistry of B. garciarum leaves as well as the diagenetic (and post-diagenetic) alterations and the paleoenvironmental conditions where the parent plants were inhabiting.

Among six chemical elements, 14 EDS ratios were selected (N/S, N/ $\mathrm{Cl}, \mathrm{N} / \mathrm{K}, \mathrm{N} / \mathrm{Ca}, \mathrm{N} / \mathrm{Na}, \mathrm{S} / \mathrm{Cl}, \mathrm{S} / \mathrm{K}, \mathrm{S} / \mathrm{Ca}, \mathrm{S} / \mathrm{Na}, \mathrm{Cl} / \mathrm{K}, \mathrm{Cl} / \mathrm{Ca}, \mathrm{Cl} / \mathrm{Na}, \mathrm{K} / \mathrm{Ca}, \mathrm{K} / \mathrm{Na}$ ), revealing the high precision of these results compared with former analyses where 3-5 ratios were retained: N/S, N/Cl, S/Cl, K/Ca for Baiera furcata (Ginkgoales) (Guignard et al., 2019); Cl/N, K/S, N/Ca, S/Ca, K/Ca also in Gingkoales (Ginkgoites ticoensis and G. skottsbergii) (Guignard et al., 2016); N/F, N/Cl, F/Cl, K/Ca in Suturovagina intermedia and N/S, $\mathrm{N} / \mathrm{Cl}, \mathrm{N} / \mathrm{K}$ in Pseudofrenelopsis dalatzensis and P. gansuensis of the Coniferales (Cheirolepidiaceae) (Yang et al., 2018; Guignard et al., 2017).

Although the number of data is still too small, some highlights can be observed: Ca is quite frequent in the few fossils cuticles checked, the ratio $\mathrm{N} / \mathrm{Cl}$ ( or $\mathrm{Cl} / \mathrm{N})$ is always observed and it seems to be a characteristic of all types of cuticles. Concerning the Coniferales, it seems that the ratios are not very homogeneous: N/S and N/K are common between the two taxa of Pseudofrenelopsis and in Brachyphyllum garciarum sp. nov., while $\mathrm{K} / \mathrm{Ca}$ is common between Suturovagina and the $B$. garciarum sp. nov. However, with these first data the 10 remaining following ratios may be considered at least as specific for $B$. garciarum sp. nov.: N/Ca, N/Na, S/Cl, S/K, S/Ca, S/Na, Cl/K, Cl/Ca, Cl/Na, K/Na.

Within one type of cuticle (Table 3), using the Mann-Whitney test, there is much more heterogeneity between the layers and cell wall and hypodermis than homogeneity, revealing the interest of this detailed study where elements do not seem to be present randomly in the cuticle, from the outermost to the innermost part. For instance (supplementary material Appendix B), only two ratios show a gradual increase (N/Ca in lower cuticle, from 1.25 in A2 layer to 2.12 in hypodermis) or decrease (K/Ca in upper cuticle, from 3.96 in A2 layer to 1.50 in hypodermis), the rest do not seem to be related between the four evaluated zones. This is congruent with former chemotaxonomical studies where just the Al layer may be an element of distinction between genera or species such as: gymnosperms in D'Angelo et al. (2010); seed ferns, conifers and cycad-related fossils (D'Angelo and Zodrow, 2011; D'Angelo et al., 2011); pteridophyll cuticles in Zodrow and Mastalerz (2007); and seed ferns (D'Angelo et al., 2012; Zodrow et al., 2010). Conversely, comparing each layer between the upper and lower cuticles (Table 3, right side), there is a great homogeneity of each layer or cell wall or hypodermis between the two types of cuticles of this taxon, enhancing the specific interest in the fine details of Brachyphyllum garciarum sp. nov., where the 10 previous enhanced ratios (with a minus for S/Ca with three-fourth of differences and at a very lower degree $\mathrm{N} / \mathrm{Ca}, \mathrm{S} / \mathrm{K}, \mathrm{Cl} / \mathrm{Ca}, \mathrm{Cl} / \mathrm{Na}$, all with one-fourth of differences) can be proposed as a specific identification. Beside of diagenetic 


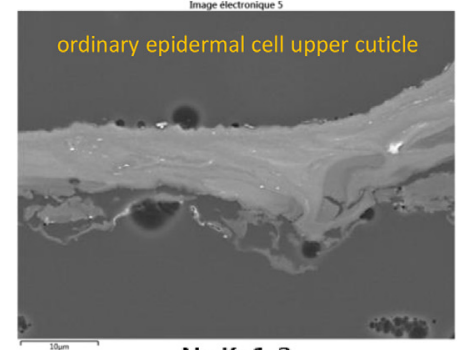

Na K $\alpha 1 \_2$

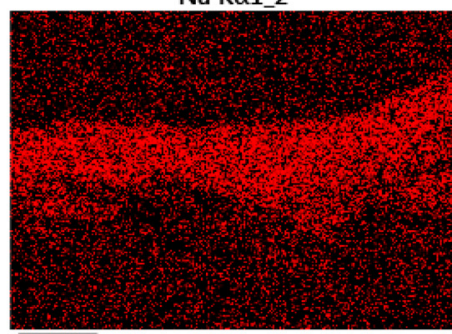

Al K $\alpha 1$
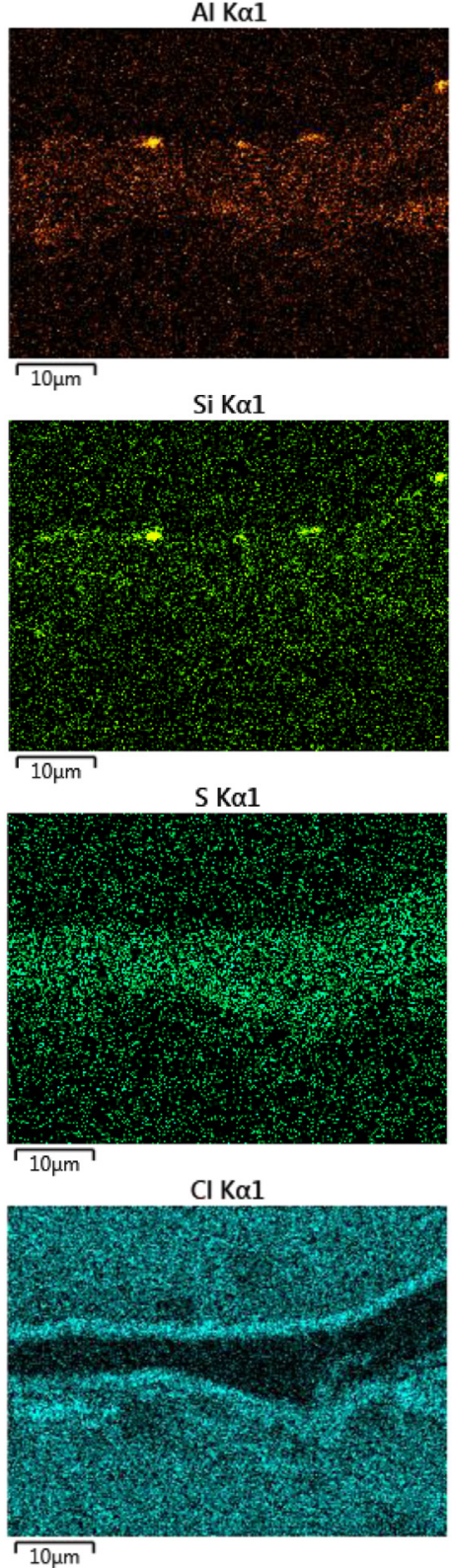

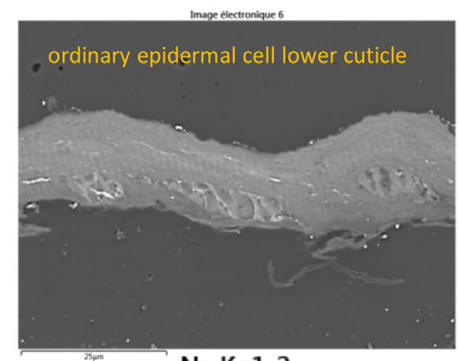

Na Ka1_2

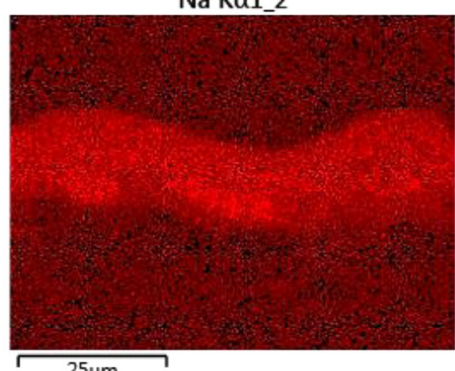

Al K $\alpha 1$

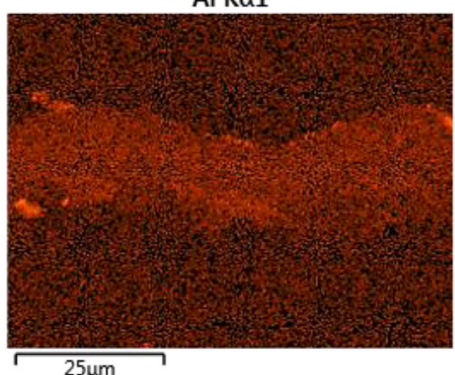

Si K $\alpha 1$

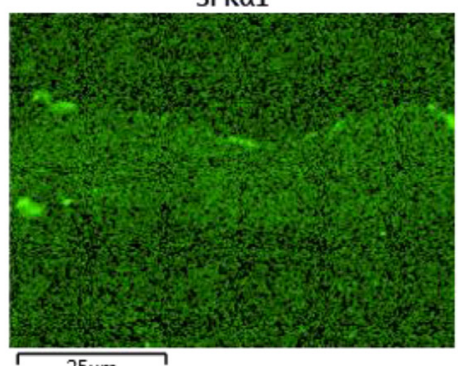

$25 \mu \mathrm{m} S \mathrm{SK \alpha}$

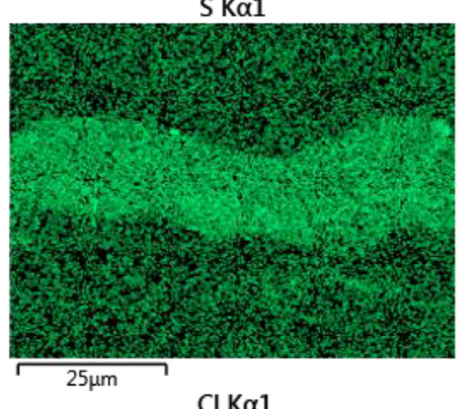

$\mathrm{Cl} \mathrm{K} \alpha 1$

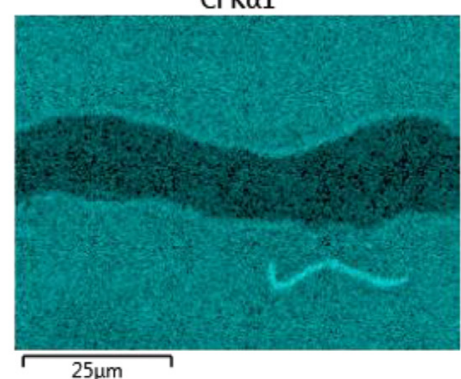

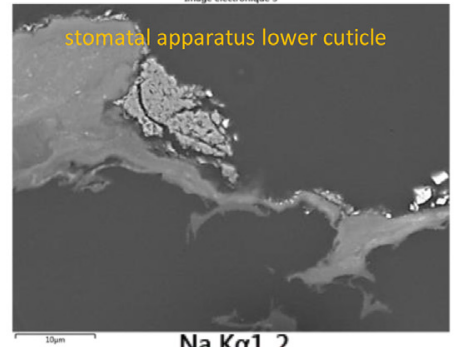

Na Ka1_2

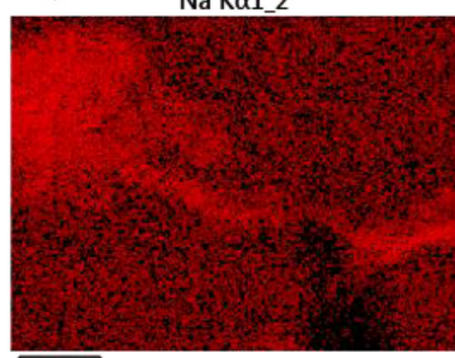

Al K $\alpha 1$

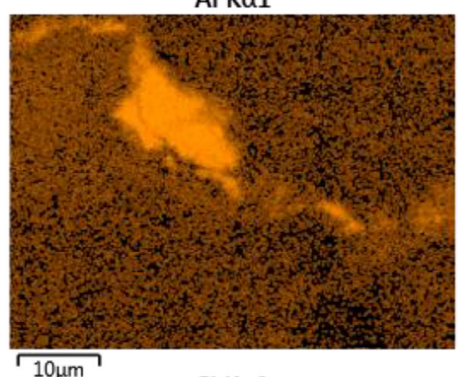

Si K $\alpha 1$

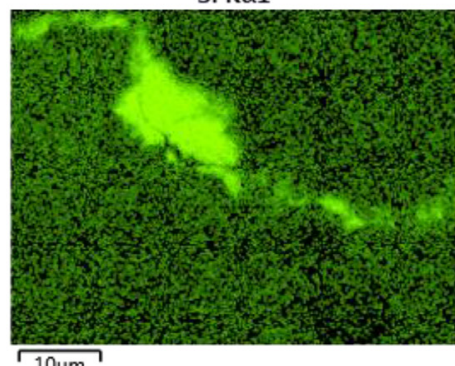

$\mathrm{S} K \alpha 1$
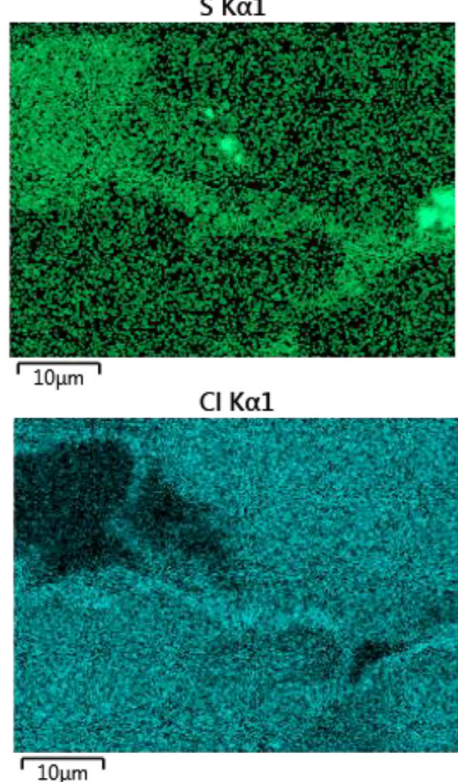

Fig. 4. Brachyphyllum garciarum sp. nov. Examples of EDS elements analysis with SEM. 


\section{Brachyphyllum garciarum sp. nov.}

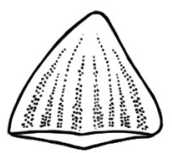

- Springhill Formation, Argentina

$-3 \mathrm{~mm}$ long $\times 3 \mathrm{~mm}$ wide

- margin entire

- stomata in narrow-edge shape groups

\section{Brachyphyllum baqueroense}

- Anfiteatro de Ticó Formation, Argentina
- $3.1 \mathrm{~mm}$ long $\mathrm{x} 1.5 \mathrm{~mm}$ wide
- margin entire
- stomata in ill-defined rows

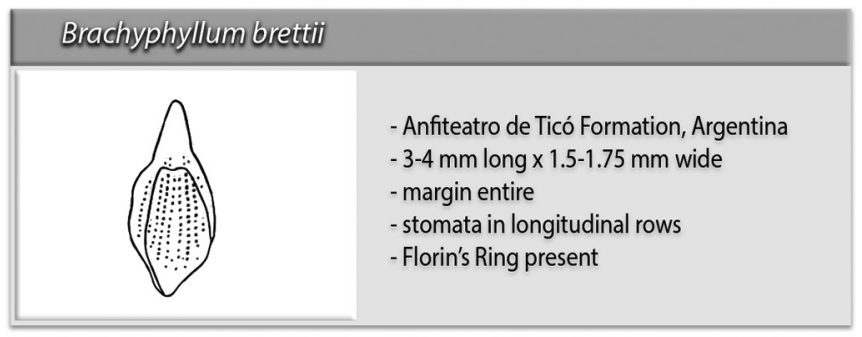
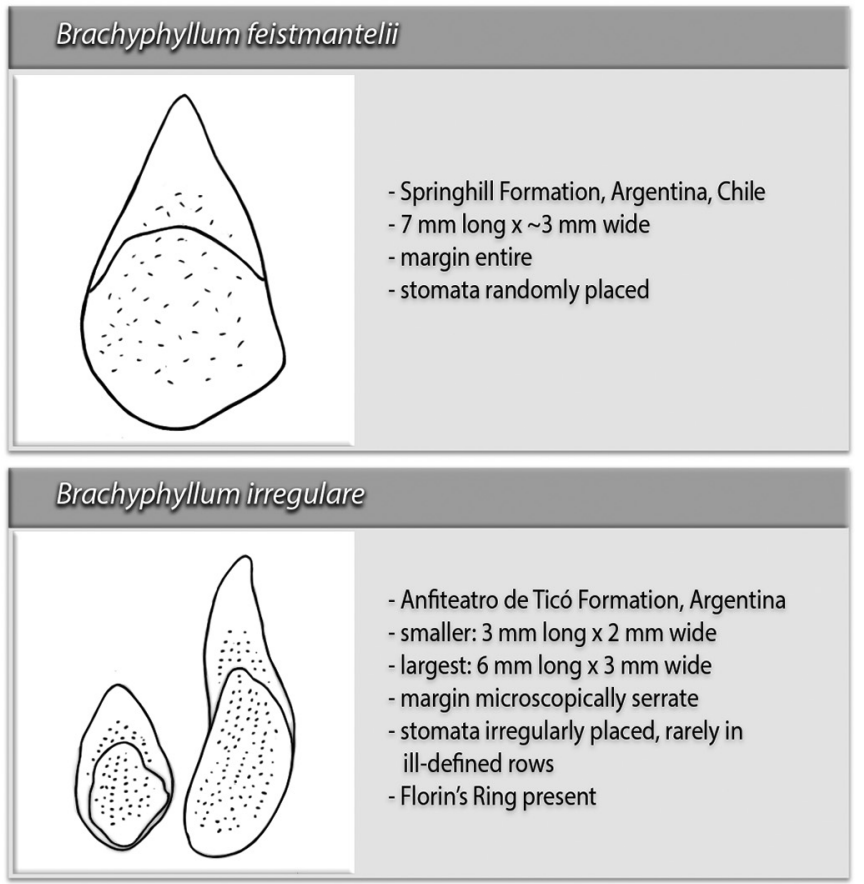

\section{Brachyphyllum kachaikensis}

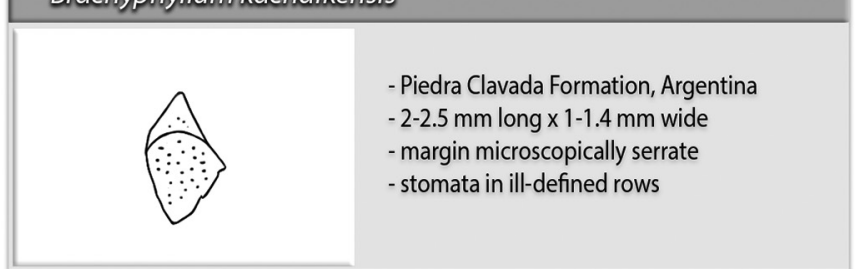

\section{Brachyphyllum mirandai}
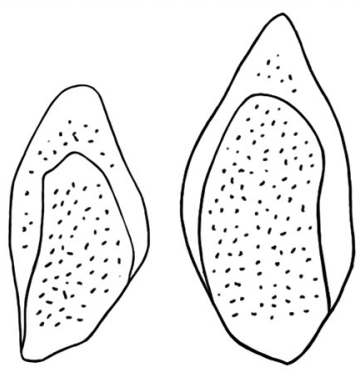

- Anfiteatro de Ticó Formation, Argentina - smaller: $4-5 \mathrm{~mm}$ long $\times$ 2-2.5 mm wide - largest : $7 \mathrm{~mm}$ long $x 4 \mathrm{~mm}$ wide - margin microscopically serrate - stomata in ill-defined rows

\section{Brachyphyllum mueronatum}

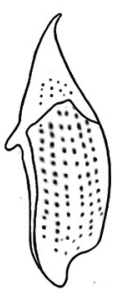

- Anfiteatro de Ticó Formation, Argentina

$-5 \mathrm{~mm}$ long $\times 1.5-1.7 \mathrm{~mm}$ wide - margin microscopically serrate

- stomata in longitudinal rows

- Florin's Ring usually present

\section{Kachaikestrobus acuminatus}

$\begin{array}{ll} & \text { - Piedra Clavada Formation, Argentina } \\ -3.6-4 \mathrm{~mm} \text { long } \times 2 \mathrm{~mm} \text { wide } \\ \text { - margin microscopically serrate } \\ \text { - stomata randomly placed } \\ \text { - papillae in both epidermis } \\ \text { - Florin's Ring present }\end{array}$

\section{Nothopehuen brevis}

- Anfiteatro de Ticó Formation, Argentina
$-2.14 \mathrm{~mm}$ long $\mathrm{x} 1.1 \mathrm{~mm}$ wide
- margin microscopically serrate
- stomata in ill-defined rows
- papillae in both epidermis

\section{Squamastrobus tigrensis}

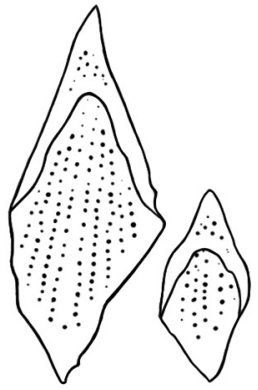

- Anfiteatro de Ticó Formation, Argentina - smaller: $2-3 \mathrm{~mm}$ long $x$ 1.3-2 mm wide - largest: $8 \mathrm{~mm}$ long $\times 3.2 \mathrm{~mm}$ wide - margin microscopically serrate - stomata in longitudinal rows

- Florin's Ring present

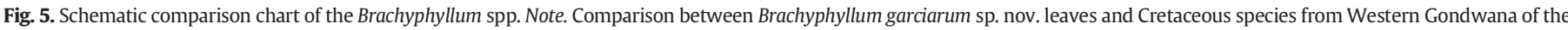

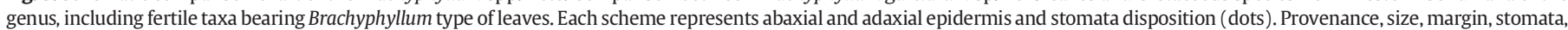
and presence of papillae or Florin's ring are also indicated. 

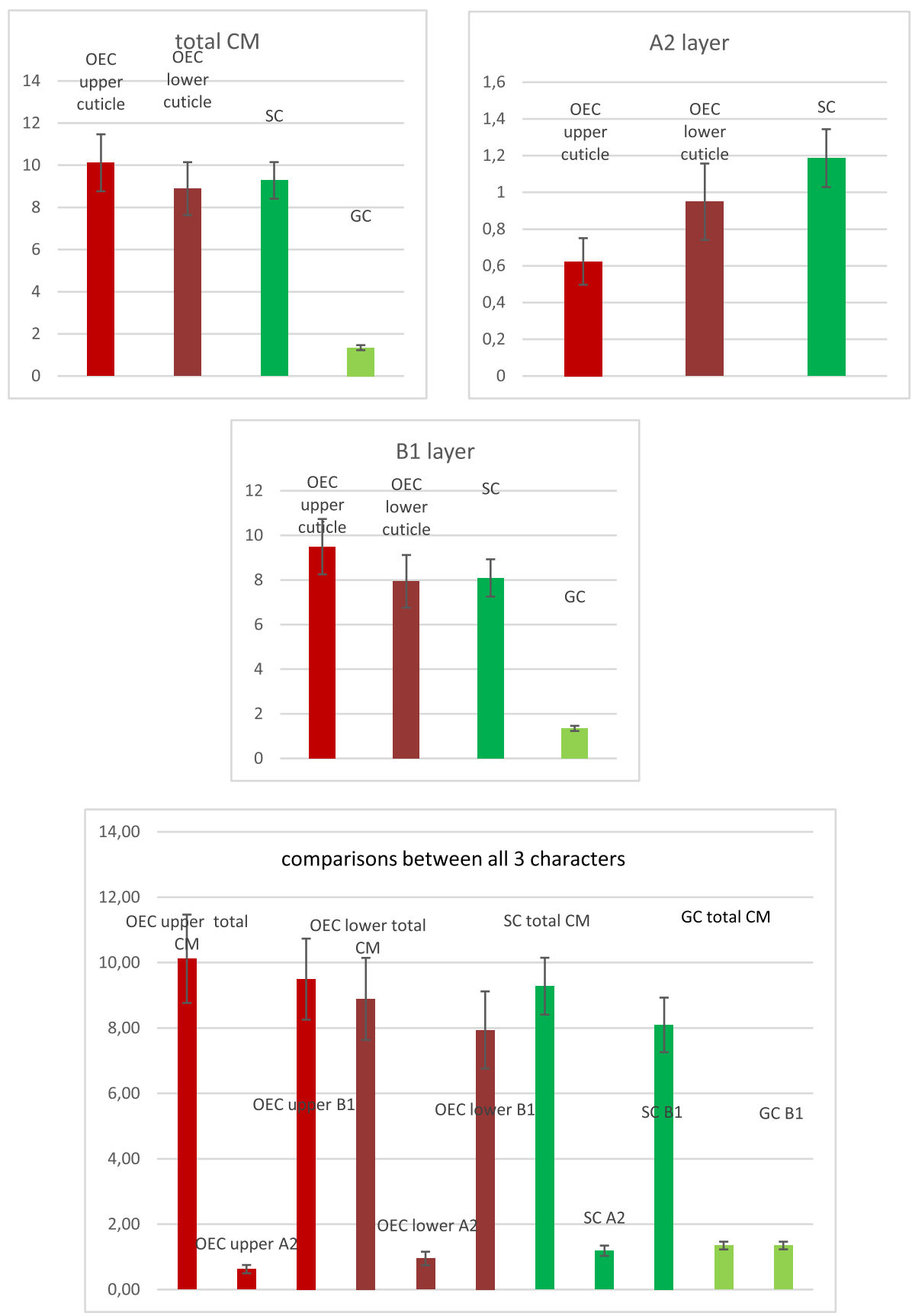

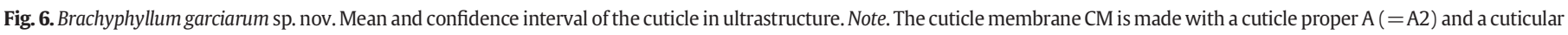
layer B (= B1). OEC = ordinary epidermal cell cuticle, SC and GC = subsidiary and guard cell cuticles.

processes that can be involved in chemical composition of fossil cuticles, compared with previous EDS cuticle studies where comparisons were made between different taxa (or with one taxon from different paleoenvironments), this first study on EDS element ratios on one taxon from one locality can be considered as a starting point for further comparisons with other taxa of this genus in the family. Although the present material comes from only one locality, in future studies the influence of the paleoenvironment on EDS could also be envisaged too. A recent study in another Coniferales family (Suturovagina intermedia, Cheirolepidiaceae; Yang et al., 2018) showed that this species had 11 EDS ratios (for A1 layer: N/F, N/Cl, F/Cl, K/Cl; for A2 layer: N/F, N/Cl, F/ $\mathrm{Cl}$; for B1 layer: N/F, F/Cl, K/ Ca; for B2 layer: N/F) related with differences of environment (less or more xerothermic).

Some remarks on cell remnants can be done, although they are not cuticle, as they are very rarely observed. These remnants in
Brachyphyllum garciarum sp. nov. are very amorphous and darkly stained in all the observations and no details could be obtained compared with other studies (Guignard et al., 2019). However, their presence in Coniferales (Araucariaceae) is quite new as cell remnants are mostly found in Cenozoic sediments and mostly in angiosperms (Niklas et al., 1978; Niklas and Brown, 1981; Niklas, 1983; Niklas et al., 1985; Schoenhut et al., 2004; Shen et al., 2016). Nevertheless, they are actually being observed more frequently in older periods like the Mesozoic in gymnosperms sensu lato, i.e. Ginkgoales (Ginkgoites ticoensis, Del Fueyo et al., 2013; Baiera furcata, Guignard et al., 2019) and Coniferales (Cheirolepidiaceae, Suturovagina intermedia, Yang et al., 2018; Cheirolepidiaceae, Hirmeriella muensteri, Guignard et al., 1998; Miroviaceae, Mirovia kazachstanica, M. macrophylla, M. sibirica, Nosova et al., 2016). The EDS ratio values obtained by TEM and tested with the Mann-Whitney test (supplementary material Appendix C) show a 


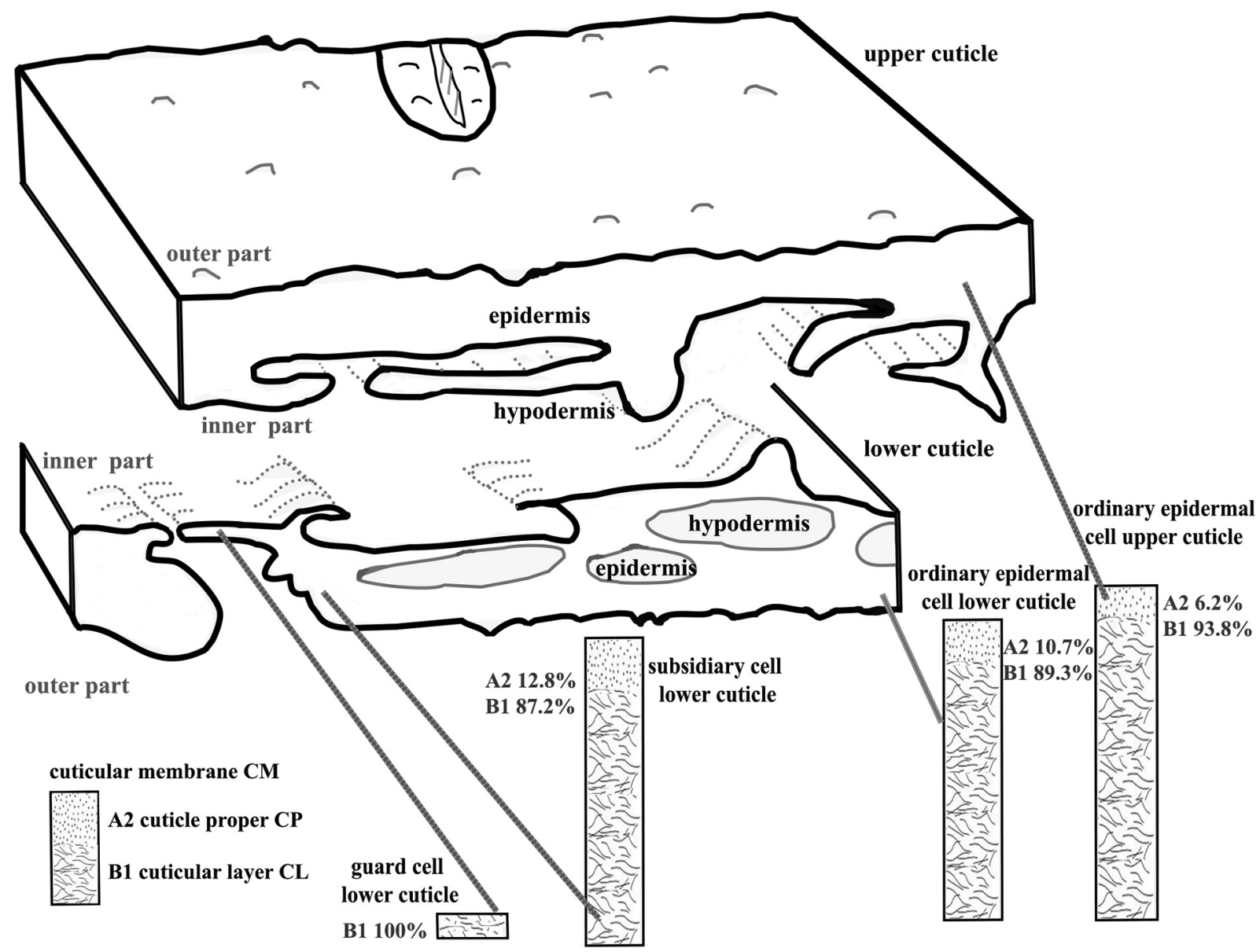

Fig. 7. Brachyphyllum garciarum sp. nov. Three-dimensional reconstruction of the cuticles.

total homogeneity between cell remnants of upper and lower cuticles, and also very different ratio values with the cuticle data, revealing the real identity of this material. This corresponds to the different comparison-spectra obtained by SEM between A2-B1 and cell remnants (Fig. 8) where absolute values are shown. Moreover, this identity could potentially be a specific character, as very different values of cell remnants ratios for Baiera furcata (Ginkgoales, Guignard et al., 2019) were obtained (Appendix C): for the 4 ratios of this study, the mean for N/S, $\mathrm{N} / \mathrm{Cl}, \mathrm{S} / \mathrm{Cl}$ and $\mathrm{K} / \mathrm{Ca}$ were $0.57,0.9,1.6$ and 0.14 respectively, while for B. garciarum sp. nov. the values were $0.35-0.36,0.25-0.26,0.70$ and $0.49-0.64$, respectively.

\subsection{Paleoenvironment at Río Correntoso locality}

\subsubsection{Paleoenvironment of the Springhill Formation and the foliar} epidermis

The geological evidence, such as a high percentage of quartz, moderate amounts of kaolinite, almost absent feldspar in the rocks, and the presence of massive, grayish mudstones with incipient pedogenetic features, along with the dominance of fern spores indicated by the palynological data, suggest that the Springhill Formation was developed during the prevalence of a humid-wet environment (Riccardi, 1971; Baldoni and Archangelsky, 1983; Archangelsky and Archanglelsky, 2004; Schwarz et al., 2011). In the epidermis of several taxa belonging to the megaflora of the Springhill Formation, the occurrence of trichomes (different types of papillae, simple and branched hairs), sunken stomata, cuticular striations and a thick cuticle are some of the most common foliar features that are shared among the different species regardless of their taxonomic position. One or more of those features were described in the pteridosperm Ruflorinia orlandoi (Carrizo et al., 2014), in the cycadal Ticoa harrisii (Carrizo and Del Fueyo, 2015), and in the species of the Ginkgoales (Baiera), Coniferales (Elatocladus, Brachyphyllum) and Bennettitales (Ptilophyllum, Otozamites) (Carrizo and Del Fueyo, 2015). Although these features are generally considered as typical xeromorphic characters (Fahn and Cutler, 1992), the studies of Hill (1998a,b) made in different proteaceous taxa (extant and fossils) from Australia, and the detailed analysis of the ecological significance of leaf and cuticular micromorphology made by Haworth and McElwain (2008, 2009), have already stated that the occurrence of trichomes, sunken stomata, cuticular striations and a thick cuticle is also recurrent on plants growing in wet environments characterized by a high rate of precipitation. Therefore, the cuticular features shown by the species of the Springhill Formation's megaflora complement the geological and palynological evidence about a humid-wet paleoenvironment during the deposition of this geological unit.

The epidermis of Brachyphyllum garciarum sp. nov. is characterized by sunken stomata and a thick cuticle of approximately $10 \mu \mathrm{m}$. Usually, thicker cuticle is more effective as a barrier to the diffusion of water, which is a common feature in plants inhabiting stressful conditions, particularly in arid environments. As an example, the Araucaria grandifolia OEC cuticle is also around $10 \mu \mathrm{m}$ thick and lived in a fluvial system with an intense volcanic activity and a periodical volcanic-ash fall (Del Fueyo and Archangelsky, 2002). In the Springhill Formation there are neither indicators of heavy volcanic activity nor arid conditions; however, the gradual transition from fluvial to estuarine, and, later, to a marine setting, that characterize the Springhill Formation may have generated a fluctuating climate, especially when the marine setting could have impacted the salinity 
Table 3

EDS Mann-Whitney tests, comparisons between the cuticles.

\begin{tabular}{|c|c|c|c|c|c|c|c|c|c|c|c|c|}
\hline & \multicolumn{4}{|c|}{ upper cuticle } & \multicolumn{4}{|c|}{ lower cuticle } & \multicolumn{4}{|c|}{$\begin{array}{l}\text { Differences /or not between upper } \\
\text { and lower cuticles }\end{array}$} \\
\hline & A2 & B1 & $\mathrm{CW}$ & hyp & A2 & B1 & $\mathrm{CW}$ & hyp & $\mathrm{A} 2$ & B1 & $\mathrm{CW}$ & hyp \\
\hline $\begin{array}{c}\text { ratio } \\
\text { mean } \\
\mathrm{N} / \mathrm{S}\end{array}$ & \multicolumn{4}{|c|}{ from 0.15 to 0.24} & \multicolumn{2}{|c|}{$\begin{array}{c}\text { from } 0.16 \text { to } \\
0.18\end{array}$} & 0.24 & 0.19 & $\begin{array}{l}\text { from } 0.16 \\
\text { to } 0.22\end{array}$ & $\begin{array}{c}\text { from } \\
0.15 \\
\text { to } \\
0.18 \\
\end{array}$ & 0.24 & $\begin{array}{c}\text { from } \\
0.17 \\
\text { to } \\
0.19 \\
\end{array}$ \\
\hline $\begin{array}{c}\text { ratio } \\
\text { mean } \\
\mathrm{N} / \mathrm{Cl}\end{array}$ & \multicolumn{4}{|c|}{ from 0.13 to 0.27} & \multicolumn{2}{|c|}{$\begin{array}{l}\text { from } 0.18 \text { to } \\
0.22\end{array}$} & 0.12 & 0.19 & $\begin{array}{l}\text { from } 0.18 \\
\text { to } 0.26\end{array}$ & $\begin{array}{c}\text { from } \\
0.22 \\
\text { to } \\
0.27\end{array}$ & $\begin{array}{l}\text { from } \\
0.12 \\
\text { to } \\
0.13 \\
\end{array}$ & $\begin{array}{c}\text { from } \\
0.19 \\
\text { to } \\
0.20 \\
\end{array}$ \\
\hline $\begin{array}{c}\text { ratio } \\
\text { mean } \\
\mathrm{N} / \mathrm{K}\end{array}$ & \multicolumn{2}{|c|}{$\begin{array}{c}\text { from } 0.97 \text { to } \\
1.28\end{array}$} & \multicolumn{2}{|c|}{$\begin{array}{l}\text { from } 1.41 \text { to } \\
1.74\end{array}$} & \multicolumn{4}{|c|}{ from 0.93 to 1.34} & $\begin{array}{l}\text { from } 0.93 \\
\text { to } 1.28\end{array}$ & $\begin{array}{c}\text { from } \\
0.97 \\
\text { to } \\
0.98 \\
\end{array}$ & $\begin{array}{l}\text { from } \\
1.34 \\
\text { to } \\
1.41 \\
\end{array}$ & $\begin{array}{c}\text { from } \\
1.23 \\
\text { to } \\
1.74 \\
\end{array}$ \\
\hline $\begin{array}{l}\text { ratio } \\
\text { mean } \\
\mathrm{N} / \mathrm{Ca}\end{array}$ & 4.99 & 2.29 & 2.58 & 2.62 & \multicolumn{4}{|c|}{ from 0.16 to 0.22} & $1.25-4.99$ & $\begin{array}{c}\text { from } \\
1.70 \\
\text { to } \\
2.29 \\
\end{array}$ & $\begin{array}{c}\text { from } \\
1.99 \\
\text { to } \\
2.58\end{array}$ & $\begin{array}{c}\text { from } \\
2.12 \\
\text { to } \\
2.62\end{array}$ \\
\hline $\begin{array}{l}\text { ratio } \\
\text { mean } \\
\mathrm{N} / \mathrm{Na}\end{array}$ & \multicolumn{4}{|c|}{ from 0.48 to 0.80} & \multicolumn{3}{|c|}{ from 0.46 to 0.76} & 0.32 & $\begin{array}{l}\text { from } 0.46 \\
\text { to } 0.63\end{array}$ & $\begin{array}{c}\text { from } \\
0.53 \\
\text { to } \\
0.76 \\
\end{array}$ & $\begin{array}{l}\text { from } \\
0.69 \\
\text { to } \\
0.80 \\
\end{array}$ & $\begin{array}{c}\text { from } \\
0.32 \\
\text { to } \\
0.48 \\
\end{array}$ \\
\hline $\begin{array}{c}\text { ratio } \\
\text { mean } \\
\mathrm{S} / \mathrm{Cl}\end{array}$ & \multicolumn{2}{|c|}{$\begin{array}{c}\text { from } 1.20 \text { to } \\
1.71\end{array}$} & \multicolumn{2}{|c|}{$\begin{array}{c}\text { from } 0.58 \text { to } \\
1.23\end{array}$} & \multicolumn{2}{|c|}{$\begin{array}{l}\text { from } 1.22 \text { to } \\
1.26\end{array}$} & 0.48 & 0.99 & $\begin{array}{l}\text { from } 1.20 \\
\text { to } 1.22\end{array}$ & $\begin{array}{c}\text { from } \\
0.76 \\
\text { to } \\
1.26 \\
\end{array}$ & $\begin{array}{l}\text { from } \\
0.48 \\
\text { to } \\
0.58 \\
\end{array}$ & $\begin{array}{c}\text { from } \\
0.99 \\
\text { to } \\
1.23\end{array}$ \\
\hline $\begin{array}{c}\text { ratio } \\
\text { mean } \\
\mathrm{S} / \mathrm{K}\end{array}$ & \multicolumn{3}{|c|}{ from 5.96 to 7.53} & 10.35 & \multicolumn{4}{|c|}{ from 5.37 to 6.63} & $\begin{array}{l}\text { from } 5.47 \\
\text { to } 5.96\end{array}$ & $\begin{array}{c}\text { from } \\
5.37 \\
\text { to } \\
7.53 \\
\end{array}$ & $\begin{array}{l}\text { from } \\
5.51 \\
\text { to } \\
6.21 \\
\end{array}$ & $\begin{array}{l}6.63- \\
10.35\end{array}$ \\
\hline $\begin{array}{c}\text { ratio } \\
\text { mean } \\
\mathrm{S} / \mathrm{Ca}\end{array}$ & 22.98 & 14.82 & 10.96 & 5.38 & \multicolumn{3}{|c|}{ from 7.67 to 8.98} & 11.19 & $7.67-22.78$ & $\begin{array}{l}8.98- \\
14.82\end{array}$ & $\begin{array}{l}8.18- \\
10.96\end{array}$ & $\begin{array}{c}\text { from } \\
11.19 \\
\text { to } \\
15.38\end{array}$ \\
\hline $\begin{array}{l}\text { ratio } \\
\text { mean } \\
\mathrm{S} / \mathrm{Na}\end{array}$ & \multicolumn{4}{|c|}{ from 2.77 to 3.28} & 2.99 & 4.28 & 2.81 & 1.72 & $\begin{array}{l}\text { from } 2.88 \\
\text { to } 2.99\end{array}$ & $\begin{array}{c}\text { from } \\
3.08 \\
\text { to } \\
4.28\end{array}$ & $\begin{array}{c}\text { from } \\
2.81 \\
\text { to } \\
3.28 \\
\end{array}$ & $\begin{array}{c}\text { from } \\
1.72 \\
\text { to } \\
2.77\end{array}$ \\
\hline $\begin{array}{c}\text { ratio } \\
\text { mean } \\
\mathrm{Cl} / \mathrm{K}\end{array}$ & \multicolumn{2}{|c|}{$\begin{array}{l}\text { from } 4.62 \text { to } \\
4.95\end{array}$} & \multicolumn{2}{|c|}{$\begin{array}{l}\text { from } 8.71 \text { to } \\
11.13\end{array}$} & \multicolumn{2}{|c|}{$\begin{array}{c}\text { from } 4.63 \text { to } \\
4.76\end{array}$} & 11.88 & 6.96 & $\begin{array}{l}\text { from } 4.63 \\
\text { to } 4.95\end{array}$ & $\begin{array}{c}\text { from } \\
4.62 \\
\text { to } \\
0.22 \\
\end{array}$ & $\begin{array}{c}\text { from } \\
11.13 \\
\text { to } \\
11.88 \\
\end{array}$ & $\begin{array}{c}\text { from } \\
6.96 \\
\text { to } \\
8.71 \\
\end{array}$ \\
\hline $\begin{array}{l}\text { ratio } \\
\text { mean } \\
\mathrm{Cl} / \mathrm{Ca}\end{array}$ & 19.40 & 9.21 & from & 15 to & \multicolumn{2}{|c|}{$\begin{array}{c}\text { from } 6.44 \text { to } \\
8.51\end{array}$} & \multicolumn{2}{|c|}{$\begin{array}{c}\text { from } 11.52 \text { to } \\
18.05\end{array}$} & $6.44-19.40$ & $\begin{array}{c}\text { from } \\
4.76 \\
\text { to } \\
9.21 \\
\end{array}$ & $\begin{array}{c}\text { from } \\
18.05 \\
\text { to } \\
20.23\end{array}$ & $\begin{array}{c}\text { from } \\
11.52 \\
\text { to } \\
13.15\end{array}$ \\
\hline $\begin{array}{l}\text { ratio } \\
\text { mean } \\
\mathrm{Cl} / \mathrm{Na}\end{array}$ & \multicolumn{2}{|c|}{$\begin{array}{c}\text { from } 1.85 \text { to } \\
2.43\end{array}$} & 6.42 & 2.21 & \multicolumn{3}{|c|}{ from 3.80 to 6.12} & 1.79 & $\begin{array}{c}\text { from } 2.43 \\
\text { to } 2.48\end{array}$ & $\begin{array}{l}1.85- \\
3.80\end{array}$ & $\begin{array}{c}\text { from } \\
6.12 \\
\text { to } \\
6.42 \\
\end{array}$ & $\begin{array}{c}\text { from } \\
1.79 \\
\text { to } \\
2.21 \\
\end{array}$ \\
\hline $\begin{array}{l}\text { ratio } \\
\text { mean } \\
\mathrm{K} / \mathrm{Ca}\end{array}$ & 3.96 & 2.28 & 1.84 & 1.50 & \multicolumn{4}{|c|}{ from 1.42 to 1.74} & $1.42-3.96$ & $\begin{array}{c}\text { from } \\
1.68 \\
\text { to } \\
2.28 \\
\end{array}$ & $\begin{array}{c}\text { from } \\
1.53 \\
\text { to } \\
1.84 \\
\end{array}$ & $\begin{array}{c}\text { from } \\
1.50 \\
\text { to } \\
1.74 \\
\end{array}$ \\
\hline $\begin{array}{l}\text { ratio } \\
\text { mean } \\
\mathrm{K} / \mathrm{Na}\end{array}$ & \multicolumn{4}{|c|}{ from 0.26 to 0.57} & \multicolumn{2}{|c|}{$\begin{array}{c}\text { from } 0.56 \text { to } \\
0.80\end{array}$} & 0.53 & 0.27 & $\begin{array}{l}\text { from } 0.50 \\
\text { to } 0.56\end{array}$ & $\begin{array}{c}\text { from } \\
0.52 \\
\text { to } \\
0.80 \\
\end{array}$ & $\begin{array}{c}\text { from } \\
0.53 \\
\text { to } \\
0.57 \\
\end{array}$ & $\begin{array}{c}\text { from } \\
0.26 \\
\text { to } \\
0.27\end{array}$ \\
\hline
\end{tabular}

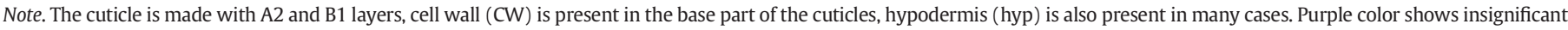
differences between these four zones, yellow color shows significant differences.

of the land, as it happens in modern coastal environment, where the ocean's salinity dispels tiny droplets of sodium into the air (Slamova et al., 2012; Thornton et al., 2010). Additionally, a thick cuticle is also considered as an adaptation to protect the leaf against predation, excessive light and toxic atmospheric gases, and also as a response to soil-nutrient deficiencies or even as a mechanism to maintain the leaf integrity, while sunken stomata may restrict water entering the stomatal pore in high precipitation stages (Haworth and McElwain, 2008).

\subsubsection{Paleoenvironment and EDS ratios}

As they are the first EDS-ratios made on an araucariacean cuticle from the Río Correntoso locality, comparisons with other paleoenvironments are not available. Moreover, as it was stated above, cuticles may have 

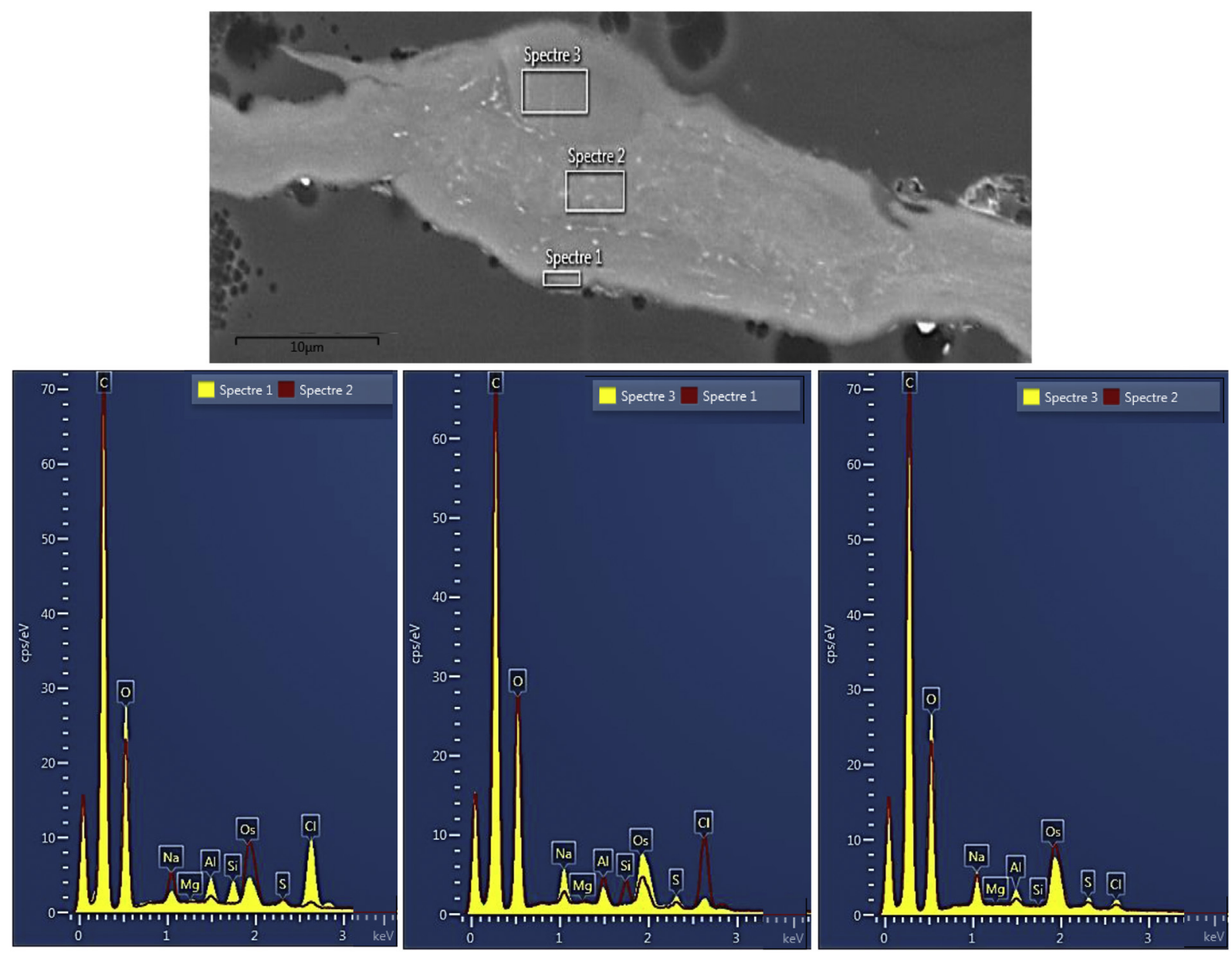

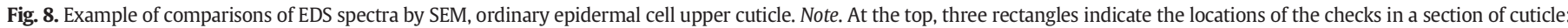

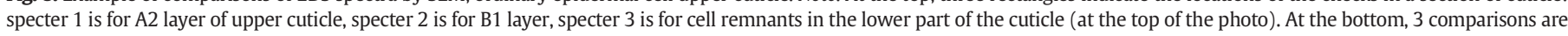

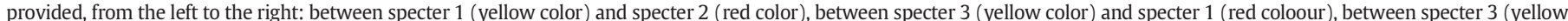
clour) and specter 2 (red color).

experienced diagenetic processes and chemical elements may have changed. However, by comparing upper and lower cuticle ratios of Brachyphyllum garciarum sp. nov., though supposed to be similar for diagenetic processes, some precise points of the functioning plant itself can be established. The presence of Ca is well studied in plant cuticles (Guzmán-Delgado et al., 2016). Benikhlef et al. (2013) experimented on leaves of living Arabidopsis thaliana by generating "a soft mechanical stimulation" on the leaves' surface, inducing an artificial "stress" that resulted, among others things, in a rapid increment in the calcium levels. This response is connected to a situation where the leaves might become more vulnerable, such as being in the presence of the fungus Botrytis cinerea (Ascomycota), usually known as botrytis bunch rot. As the lower cuticle of Brachyphyllum garciarum has ratios with $\mathrm{Ca}(\mathrm{Cl} / \mathrm{Ca}, \mathrm{K} /$ $\mathrm{Ca}$ ) in the layers A2, B1, cell wall and hypodermis (Table 3), almost always lower than in the upper cuticle, it could indicate a higher Ca content for the lower cuticle, and, therefore, the existence of a higher degree of stress than in the upper cuticle. Moreover, in living Pinus ponderosa and Pseudotsuga menziesii, the cuticular transpiration is revealed to be higher during exposure to chlorine gas (Schreuder and Brewer, 2001). When analyzing the lower cuticle ratios where $\mathrm{Cl}$ is present, $\mathrm{N} / \mathrm{Cl}$ and $\mathrm{S} / \mathrm{Cl}$ ratios are almost always lower, while $\mathrm{Cl} / \mathrm{K}, \mathrm{Cl} / \mathrm{Ca}$, and $\mathrm{Cl} / \mathrm{Na}$ are mainly higher, indicating a probable higher concentration of $\mathrm{Cl}$ in the lower cuticle and possibly a higher transpiration rate. These dissimilarities between the upper and lower cuticles seem to demonstrate the differences of function between the two cuticles, potentially linked with the presence of a higher number of stomatal apparatuses in the lower cuticle and more potential transpiration activity.

\section{Conclusions}

An extensive and detailed description of a new taxon, Brachyphyllum garciarum sp. nov., from the Lower Cretaceous Springhill Formation, Argentina, was carried out through the analysis of the leaf's gross morphology and the cuticle characters with LM, SEM and TEM. The studied fossils are remarkably different from the already known contemporary species of Brachyphyllum from the Cretaceous of Western Gondwana and thus a new species is herein erected.

The ultrastructure shows that of the four types of cuticle observed (OEC upper and lower cuticles, SC cuticle and GC cuticle) both fine details of OEC cuticles and the SC cuticle are similar in their constitution, presenting the A2 granular layer and the spongy B1 layer somewhat mixed with cell wall remnants. These three cuticle types show insignificant differences in thicknesses $(8.89-10.15 \mu \mathrm{m})$, and $6.2-12.8 \%$ of their total CM thickness is composed by the A2 layer, and $87.2-93.8 \%$ by the B1 layer. In contrast, the GC cuticle is significantly different than the others, being much thinner ( $1.34 \mu \mathrm{m}$ in mean) and made with the same type of B1 layer only. The affinity with the other araucarian (Coniferales) fossil plants Nothopehuen brevis and Araucaria grandifolia is revealed, and this cuticle type (A2 granular and B1 spongy) is proposed for this group at least at the species level, potentially genus or family, as it is the first detailed ultrastructure study in this group. In addition, when summarizing all the ultrastructure data known so far on GC cuticles, it seems that the GC ultrastructure in Brachyphyllum garciarum sp. nov. (made with B1 layer only) is different from those present in all other taxonomical groups. Therefore, the GC ultrastructure 
could be a taxonomical character at the family-order level. Moreover, among the extant species of Araucaria, the foliar morphology of $B$. garciarum sp. nov. has more resemblance to those present in some species of the Eutacta section than to the other sections (Araucaria, Bunya, Intermedia) of the genus. Therefore, in addition to the bract-scale complexes also referred to the Eutacta Section that are present in the deposits of the Springhill Formation, B. garciarum sp. nov. reinforces the occurrence and large area of distribution of the Eutacta Section in the fossil record during the Mesozoic of South America.

The EDS study reveals the presence of 10 characteristic ratios for B. garciarum sp. nov. with taxonomic importance at least at the species level: $\mathrm{N} / \mathrm{Na}, \mathrm{S} / \mathrm{Cl}, \mathrm{S} / \mathrm{Na}, \mathrm{Cl} / \mathrm{K}, \mathrm{K} / \mathrm{Na}$ as the most important; followed by $\mathrm{N} / \mathrm{Ca}, \mathrm{S} / \mathrm{K}, \mathrm{Cl} / \mathrm{Ca}, \mathrm{Cl} / \mathrm{Na}$; and $\mathrm{S} / \mathrm{Ca}$ being the least reliable. Three ratios, $\mathrm{N} / \mathrm{S}, \mathrm{N} / \mathrm{K}$ and $\mathrm{K} / \mathrm{Ca}$, share similarities with some Cheirolepidiaceae (Coniferales) taxa (Pseudofrenelopis and Suturovagina), while $\mathrm{N} / \mathrm{Cl}$ is present in all cuticles of all the taxonomical groups previously studied in EDS. Cell remnants show insignificant differences between upper and lower cuticles, and compared with former data, these 14 cell remnants ratios could also reveal to be of specific importance.

The epidermal analysis made on the leaves of Brachyphyllum garciarum sp. nov. also showed the presence of a thick cuticle and sunken stomata, which is in concordance with the general cuticular morphology present in most species of the Springhill Formation's megaflora. This is interpreted as a result of the adaptation to the wet climate and the gradual transition from a fluvial to an estuarine and, later, marine setting that characterize the Springhill Formation deposits.

\section{Acknowledgements}

This research was partially supported by grants CONICET PIP 212/12, PICT 528/12 and PICT 2206/2015. The authors are grateful to Antonello Bartiromo and the anonymous reviewer for all their valuable suggestions that have greatly improved the manuscript. We express our special thanks to Orlando Cárdenas for his unconditional help and support during the field trips and technical assistance in cuticles processing. Also to Marcelo Miñana for his help in many aspects of the field logistics. We thank the owners and employees of the Estancia Suyai (Vladimiro Macharashvili, Santiago and Miguel Crozzoli, Griselda Garrido, Raquel Cuevas), Estancia El Correntoso (Nélida and Emilio Cvjetanovic) and Estancia El Salitral (Élida and Sebastián García) who kindly gave us permission to prospect and visit the fossiliferous localities situated in their properties. We also wish to thank the technical staff of the University Lyon 1 "centre technologique des microstructures CT $\mu$ ", especially Xavier Jaurand, Veronica La Padula and Charline Dalverny for technical improvement of the study, and the English linguist Gastón Lopez Rosales, for all their valuable comments and corrections.

\section{Appendix A. Supplementary data}

Supplementary data to this article can be found online at https://doi. org/10.1016/j.revpalbo.2019.06.014.

\section{References}

Arbe, H.A., 2002. Análisis estratigráfico del Cretácico de la Cuenca Austral. In: Haller, M.J. (Ed.), Geología y Recursos Naturales de Santa Cruz. Relatorio del XV Congreso Geológico Argentino. El Calafate, Buenos Aires, pp. 407-420.

Archangelsky, S., 1963. A new Mesozoic flora from Ticó, Santa Cruz Province, Argentina. Bulle. Br. Mus. (Nat. Hist.), Geol. 8, 45-92.

Archangelsky, S., 1976. Vegetales fósiles de la Formación Springhill, Cretácico, en el subsuelo de la Cuenca Magallánica, Chile. Ameghiniana 13, 141-158.

Archangelsky, S., Archanglelsky, A., 2004. Palinología estadística en el Cretácico de la Cuenca Austral, Plataforma Continental Argentina. II. Seis perforaciones del área Gallegos. III. Discusión y conclusiones. Revista del Museo Argentino de Ciencias Naturales (Nueva Serie) 6, 245-255.

Archangelsky, S., Del Fueyo, G.M., 1989. Squamastrobus gen. n., a fertile podocarp from the Early Cretaceous of Patagonia, Argentina. Rev. Palaeobot. Palynol. 59, 109-126.
Archangelsky, S., Baldoni, A., Gamerro, J.C., Seiler, J., 1984. Palinología estratigráfica del Cretácico de Argentina Austral. 3. Distribución de las especies y conclusiones. Ameghiniana 21, 15-33.

Archangelsky, A., Andreis, R., Archangelsky, S., Artabe, A., 1995. Cuticular characters adapted to volcanic stress in a new Cretaceous cycad leaf from Patagonia, Argentina. Considerations on the stratigraphy and depositional history of the Baqueró Formation. Rev. Palaeobot. Palynol. 89, 213-233.

Artabe, A.E., Zamuner, A.B., Archangelsky, S., 1991. Estudios cuticulares en cycadópsidas fósiles. El género Kurtziana Frenguelli 1942. Ameghiniana 28, 365-374.

Baldoni, A.M., 1979. Nuevos elementos paleoflorísticos de la tafoflora de la Formación Spring Hill, limite Jurásico-Cretácico subsuelo de Argentina y Chile Austral. Ameghiniana 16, 103-119.

Baldoni, A.M., Archangelsky, S., 1983. Palinología de la Formación Springhill (Cretácico Inferior), subsuelo de Argentina y Chile Austral. Rev. Esp. Micropaleontol. 15, 47-101.

Bartiromo, A., Guignard, G., Barone-Lumaga, M.R., Barattolo, F., Chiodini, G., Avino, R. Guerriero, G., Barale, G., 2012. Influence of volcanic gases on the epidermis of Pinus halepensis Mill. in Campi Flegrei, Southern Italy: a possible tool detecting volcanism in present and past floras. J. Volcanol. Geotherm. Res. 233-234, 1-17.

Bartiromo, A., Guignard, G., Barone-Lumaga, M.R., Barattolo, F., Chiodini, G., Avino, R., Guerriero, G., Barale, G., 2013. The cuticle micromorphology of in situ Erica arborea L. exposed to long-term volcanic gases in Phlegrean Fields, Campania, Italy. Environ. Exp. Bot. 87, 197-206.

Benikhlef, L., L'Haridon, F., Abou-Mansour, E., Serrano, M., Binda, M., Costa, A., Lehmann, S., Métraux, J.P., 2013. Perception of soft mechanical stress in Arabidopsis leaves activates disease resistance. BMC Plant Biol. 13.

Carrizo, M.A., Del Fueyo, G.M., 2015. The Early Cretaceous megaflora of the Springhill Formation, Patagonia. Paleofloristic and paleonvironmental inferences. Cretaceous Res. 56, 93-109.

Carrizo, M.A., Del Fueyo, G.M., Medina, F.A., 2014. Foliar cuticle of Ruflorinia orlandoi nov. sp. (Pteridospermophyta) from the Lower Cretaceous of Patagonia. Geobios 47, 87-99.

Carrizo, M.A., Lafuente Diaz, M.A., Del Fueyo, G.M., 2019. Resolving taxonomic problems through cuticular analysis in Early Cretaceous bennettitalean leaves from Patagonia. Cretac. Res. 97, 40-51.

Cortiñas, J.C., Arbe, H.A., 1981. Un nuevo afloramiento fosilífero de la Formación Springhill, en el Noroeste de la provincia de Santa Cruz. Rev. Asoc. Geol. Argent. 36, 212-214.

Cronquist, A., Takhtajan, A., Zimmermann, W., 1966. On the higher taxa of embryobionta. Taxon 15, 129-168.

D'Angelo, J.A., Zodrow, E.L., 2011. Chemometric study of functional groups in different layers of Trigonocarpus grandis ovules (Pennsylvanian seed fern, Canada). Org. Geochem. 42, 1039-1054.

D'Angelo, J.A., Zodrow, E.L., Camargo, A., 2010. Chemometric study of functional groups in Pennsylvanian gymnosperm plant organs (Sydney Coalfield, Canada): implications for chemotaxonomy and assessment of kerogen formation. Org. Geochem. 41, 1312-1325.

D'Angelo, J.A., Escudero, L.B., Volkheimer, W., Zodrow, E.L., 2011. Chemometric analysis of functional groups in fossil remains of the Dicroidium flora (Cacheuta, Mendoza, Argentina): Implications for kerogen formation. Int. J. Coal Geol. 2, 97-111.

D'Angelo, J.A., Zodrow, E.L., Mastalerz, M., 2012. Compression map, functional groups and fossilization: a chemometric approach (Pennsylvanian neuropteroid foliage, Canada). Int. J. Coal Geol. 90, 149-155.

Del Fueyo, G., 1991. Una nueva Araucariaceae cretácica de Patagonia, Argentina. Ameghiniana 28, 149-161.

Del Fueyo, G., Archangelsky, A., 2002. Araucaria grandifolia Feruglio from the Lower Cretaceous of Patagonia, Argentina. Cretac. Res. 23, 265-277.

Del Fueyo, G., Villar de Seoane, L., Archangelsky, S., Guignard, G., 2006. Estudios cuticulares de Ginkgoites Seward del Cretácico Inferior de Patagonia. Revista del Museo Argentino de Ciencias Naturales, N.S. 8, 143-149.

Del Fueyo, G.M., Archangelsky, S., Llorens, M., Cúneo, R., 2008. Coniferous ovulate cones from the Lower Cretaceous of Santa Cruz Province, Argentina. Int. J. Plant Sci. 169, 799-813.

Del Fueyo, G., Guignard, G., Villar De Seoane, L., Archangelsky, S., 2013. Leaf cuticle anatomy and the ultrastructure of Ginkgoites ticoensis Archang. from the Aptian of Patagonia. Int. J. Plant Sci. 406-424.

Fahn, A., Cutler, D.F., 1992. Xerophytes. Borntraeger, Berlin.

Finch, P., Freeman, G., 2001. Simulated diagenesis of plant cuticles-implications for organic fossilisation. J. Anal. Appl. Pyrolysis 58-59, 229-235.

Giacosa, R., Franchi, M., 2001. Hojas Geológicas 4772-III y 4772-IV Lago Belgrano y Lago Posadas, Provincia de Santa Cruz. Servicio Geológico Minero Argentino. Instituto de Geología y Recursos Minerales. Boletín 256, Buenos Aires.

González Arismendi, G., Tappert, R., McKellar, R.C., Wolfe, A.P., Muehlenbachs, K., 2018. Deuterium exchangeability in modern and fossil plant resins. Geochim. Cosmochim. Acta 239, 159-172.

Guignard, G., 2019. Thirty-three years (1986-2019) of fossil plant cuticle studies using transmission electron microscopy: a review. Rev. Palaeobot. Palynol. this issue.

Guignard, G., Zhou, Z.Y., 2005. Comparative studies of leaf cuticle ultrastructure between living and the oldest known fossil ginkgos in China. Int. J. Plant Sci. 166, 145-156.

Guignard, G., Thevenard, F., van Konijnenburg-van Cittert, J.H.A., 1998. Cuticle ultrastructure of the cheirolepidiaceous conifer Hirmeriella muensteri (Schenk) Jung. Rev. Palaeobot. Palynol. 104, 115-141.

Guignard, G., Boka, K., Barbacka, M., 2001. Sun and shade leaves? Cuticle ultrastructure of Jurassic Komlopteris nordenskioeldii (Nathorst) Barbacka. Rev. Palaeobot. Palynol. 114, 191-208.

Guignard, G., Popa, M., Barale, G., 2004. Ultrastructure of Early Jurassic fossil plant cuticles: Pachypteris gradinarui Popa. Tissue Cell 36, 263-273. 
Guignard, G., Del Fueyo, G.M., Villar de Seoane, L., Carrizo, M.A., Lafuente Diaz, M.A., 2016 Insights into the leaf cuticle fine structure of Ginkgoites skottsbergii Lund. from the Albian of Patagonia and its relationship within Ginkgoaceae. Rev. Palaeobot. Palynol. 232, 22-39.

Guignard, G., Yang, X.J., Wang, Y.D., 2017. Cuticle ultrastructure of Pseudofrenelopsis gansuensis: further taxonomical implications for Cheirolepidiaceae. Cretac. Res. 71, 24-39.

Guignard, G., Yang, X.J., Wang, Y.D., 2019. Cuticle ultrastructure of Baiera-like leaves: taxonomic and palaeoecological implications. Rev. Palaeobot. Palynol. this issue.

Gupta, N.S., Michels, R., Briggs, D.E., Collinson, M.E., Evershed, R.P., Pancost, R.D., 2007a. Experimental evidence for the formation of geomacromolecules from plant leaf lipids. Org. Geochem. 38, 28-36.

Gupta, N.S., Briggs, D.E., Collinson, M.E., Evershed, R.P., Michels, R., Jack, K.S., Pancost, R.D., 2007b. Evidence for the in situ polymerisation of labile aliphatic organic compounds during the preservation of fossil leaves: implications for organic matter preservation. Org. Geochem. 38, 499-522.

Guzmán-Delgado, P., Graçab, J., Cabralb, V., Gil, L., Fernández, V., 2016. The presence of cutan limits the interpretation of cuticular chemistry and structure: Ficus elastica leaf as an example. Physiol. Plant. 157, 205-220.

Harris, T.M., 1979. The Yorkshire Jurassic Flora V. Coniferales. British Museum (Natural History), London.

Haworth, M., McElwain, J., 2008. Hot, dry, wet, cold or toxic? Revisiting the ecological significance of leaf and cuticular micromorphology. Palaeogeogr. Palaeoclimatol. Palaeoecol. 262, 79-90.

Haworth, M., McElwain, J.C., 2009. Reply to the comment on "Hot, dry, wet, cold or toxic? Revisiting the ecological significance of leaf cuticular micromorphology" by M. Haworth and J.C. McElwain [Palaeogeography, Palaeoclimatology, Palaeoecology 262 (2008) 79-90]. Palaeogeogr. Palaeoclimatol. Palaeoecol. 273, 209-211.

Hill, R.S., 1998a. Fossil evidence for the onset of xeromorphy and scleromorphy in Australian Proteaceae. Aust. Syst. Bot. 11, 391-400.

Hill, R.S., 1998b. Poor soils and a dry climate: the evolution of the Australian scleromorphic and xeromorphic vegetation. Austr. Biol. 11, 26-29.

Lafuente Diaz, M.A., D'Angelo, J.A., Del Fueyo, G.M., Zodrow, E.L., 2018. Fossilization model for Squamastrobus tigrensis foliage in a volcanic-ash deposit: implications for preservation and taphonomy (Podocarpaceae, Lower Cretaceous, Argentina). Palaios 33, 323-337.

Lindley, J., Hutton, W., 1836. The fossil flora of Great Britain; or, Figures and descriptions of the vegetable remains found in a fossil state in this country. London.

Lugardon, B., 1971. Contribution à la connaissance de la morphogénèse et de la structure des parois sporales chez les Filicinées isosporées. Unpublished Thesis. Toulouse University, France.

Marynowski, L., Bucha, M., Smolarek, J., Wendorff, M., Simoneit, B.R., 2018. Occurrence and significance of mono-, di-and anhydrosaccharide biomolecules in Mesozoic and Cenozoic lignites and fossil wood. Org. Geochem. 116, 13-22.

Niklas, K.J., 1983. Organelle preservation and protoplast partitioning in fossil angiosperm leaf tissues. Am. J. Bot. 70, 543-548.

Niklas, K.J., Brown, R.M., 1981. Ultrastructural and paleobiochemical correlations among fossil leaf tissues from the St. Maries River (Clarkia) Area, Northern Idaho, USA. Am. J. Bot. 68, 332-341.

Niklas, K.J., Brown, R.M., Santos, R., Vian, B., 1978. Ultrastructure and cytochemistry of Miocene angiosperm leaf tissues. Proc. Natl Acad. Sci. USA 75, 3263-3267.

Niklas, K., Brown, R.M., Santos, R., 1985. Ultrastructural states of preservation in Clarkia angiosperm leaf tissues: implications on modes of fossilization. In: Smiley, C.J. (Ed.), Late Cenozoic History of the Pacific Northwest. American Association for Advancement of Science, Pacific Division, San Francisco, pp. 143-145.

Nosova, N., Yakovlevaa, O., Ivanovaa, A., Kiritchkovab, A., 2016. First data on the ultrastructure of the leaf cuticle of a Mesozoic conifer, Mirovia Reymanówna. Rev. Palaeobot. Palynol. 233, 115-124.

Nosova, N., Yakovleva, O., Kotina, E., 2019. First data on the leaf cuticle ultrastructure of the Mesozoic genus Pseudotorellia Florin. Rev. Palaeobot. Palynol. this issue.

Nullo, F.E., Panza, J.L., Blasco, G., 1999. Jurásico y Cretácico de la Cuenca Austral. En. In: Caminos, R. (Ed.), Geología Argentina. Anales de la Secretaría de Geología y Minería 29. Buenos Aires, pp. 528-535.

Odin, G.P., McNamara, M.E., Arwin, H., Järrendahl, K., 2018. Experimental degradation of helicoidal photonic nanostructures in scarab beetles (Coleoptera: Scarabaeidae): implications for the identification of circularly polarizing cuticle in the fossil record. J. R. Soc. Interface 15, 1-11.

Ottone, E.G., Aguirre-Urreta, M.B., 2000. Palinomorfos cretácicos de la Formación Springhill en Estancia El Salitral, Patagonia Austral, Argentina. Ameghiniana 37, 375-378.

Passalia, M.G., 2007. Nuevos registros para la flora cretácica descripta por Halle (1913) en el Lago San Martín, Santa Cruz, Argentina. Ameghiniana 44, 565-695.

Passalia, M.G., Del Fueyo, G., Archangelsky, S., 2010. An Early Cretaceous zamiaceous cycad of South West Gondwana: Restrepophyllum nov. gen. from Patagonia, Argentina. Rev. Palaeobot. Palynol. 161, 137-150.

Poiré, D.G., Franzese, J.R., Richiano, S., 2011. Estratigrafía del relleno inicial de la Cuenca Austral desde Los Antiguos a El Calafate, provincia de Santa Cruz, Argentina. Guía de Campo. (Inedit). 1-100.

Riccardi, A.C., 1971. Estratigrafía en el oriente de la Bahía de la Lancha, Lago San Martín, Santa Cruz, Argentina. Revista del Museo de La Plata (Nueva Serie) Sección Geología 7, 245-318.
Riccardi, A.C., 1976. Paleontología y edad de la Formación Springhill. Primer Congreso Geológico Chileno, 1, pp. C41-C56 Santiago, Chile.

Saitta, E.T., Kaye, T.J., Vinther, J., 2019. Sediment-encased maturation: a novel method for simulating diagenesis in organic fossil preservation. Palaeontology 62, 135-150.

Schoenhut, K., Vann, D.R., Le Page, B.A., 2004. Cytological and ultrastructural preservation in Eocene Metasequoia leaves from the Canadian High Arctic. Am. J. Bot. 91, 816-824

Schreuder, M.D.J., Brewer, C.A., 2001. Persistent effects of short-term, high exposure to chlorine gas on physiology and growth of Pinus ponderosa and Pseudotsuga menziesii. Ann. Bot. 88, 197-206.

Schwarz, E., Veiga, G.D., Spalletti, L.A., Massaferro, J.L., 2011. The transgressive infill of an inherited-vallet system: the Springhill Formation (lower cretaceous) in southern Austral Basin, Argentina. Mar. Pet. Geol. 28, 1218-1241.

Shen, H.X., Du, K.H., Wang, X., 2016. Plant cytoplasm preservation in a baked root of Abies. Palaeoworld 25, 287-291.

Simoneit, B.R., Otto, A., Kusumoto, N., Basinger, J.F., 2016. Biomarker compositions of Glyptostrobus and Metasequoia (Cupressaceae) fossils from the Eocene Buchanan Lake Formation, Axel Heiberg Island, Nunavut, Canada reflect diagenesis from terpenoids of their related extant species. Rev. Palaeobot. Palynol. 235, 81-93.

Slamova, K., Schill, C., Wiesmeier, S., Köhl, M., Glaser, R., 2012. Mapping atmospheric corrosion in coastal regions: methods and results. J. Photon. Ener. 2.

Spalletti, L.A., Schwarz, E., Veiga, G.D., Matheos, S.D., Haring, C., Covellone, G., 2009 Análisis paleoambiental y estratigráfico secuencial de alta resolución de la Formación Springhill al este de Tierra del Fuego (Cuenca Austral, Argentina). XII Congreso Geológico Chileno, Santiago. Actas, pp. 1-4.

Stockey, R.A., Ko, H., 1986. Cuticle micromorphology of Araucaria De Jussieu. Bot. Gaz. 147, 508-548.

Taylor, T.N., Taylor, E.L., Krings, M., 2009. Paleobotany: The Biology and Evolution of Fossil Plants. Second edition. Academic Press, Burlington, MA.

Thévenard, F., Barale, G., Guignard, G., Daviero-Gomez, V., Gomez, B., Philippe, M., Labert, N., 2005. Reappraisal of the ill-defined Liassic pteridosperm Dichopteris using an ultrastructural approach. Bot. J. Linn. Soc. London 149, 313-332.

Thomas, C.R., 1949. Manantiales Field, Magallanes Province, Chile. Am. Assoc. Petrol. Geol. 33, 1579-1589.

Thornton, J.A., Kercher, J.P., Riedel, T.P., Wagner, N.L., Cozic, J., Holloway, J.S., Dubé, W.P., Wolfe, G.M., Quinn, P.K., Middlebrook, A.M., Alexander, B., Brown, S.S., 2010. A large atomic chlorine source inferred from mid-continental reactive nitrogen chemistry. Nature 464, 271-274.

Traverso, N.E., 1966. Brachyphyllum tigrense, nueva conifera de la Formación Baqueró, Cretácico de Santa Cruz. Ameghiniana 4, 189-194.

Traverso, N.E., 1968. Brachyphyllum baqueroense otra nueva conífera de la Formación Baqueró, Cretácico de Santa Cruz. Ameghiniana 5, 374-378.

Villar de Seoane, L., 1999. Otozamites ornatus sp. nov., a new bennettitalean leaf species from Patagonia, Argentina. Cretac. Res. 20, 499-506.

Villar de Seoane, L., 2001. Cuticular study of Bennettitales from the Springhill Formation, Lower Cretaceous of Patagonia, Argentina. Cretac. Res. 22, 461-479.

Villar de Seoane, L., 2003. Cuticle ultrastructure of the Bennettitales from the Anfiteatro de Ticó Formation (early Aptian), Santa Cruz Province, Argentina. Rev. Palaeobot. Palynol. 127, 59-76.

Wang, Y.D., Guignard, G., Thévenard, F. Dilcher, D. Barale, G., Mosbrügger, V., Yang X.J. Mei, S.W., 2005. Cuticular Anatomy of Sphenobaiera huangii (Ginkgoales) from the Lower Jurassic of Hubei, China. Am. J. Bot. 92, 709-721.

Wilde, M.H., Eames, A.J., 1952. The ovule and seed of Araucaria bidwillii with discussion of the taxonomy of the genus. II. Taxonomy. Ann. Bot. (New Series) 16, 27-47.

Yang, X.-J., Guignard, G., Thevenard, F., Wang, Y., Barale, G., 2009. Leaf cuticle ultrastructure of Pseudofrenelopsis dalatzensis (Chow et Tsao) Cao ex Zhou (Cheirolepidiaceae) from the Lower Cretaceous Dalazi Formation of Jilin, China. Rev. Palaeobot. Palynol. $153,8-18$.

Yang, X.-J., Guignard, G., Zhou, Z.-Y., Xu, Q., 2018. Suturovagina intermedia (Cheirolepidiaceae) from the upper Lower Cretaceous Dalazi Formation of Wangqing, Northeast China: cuticle ultrastructure and palaeoenvironmental insights. Cretaceous Research 80-99.

Zhou, Z.-Y., Guignard, G., 1998. Leaf cuticle ultrastructure of two czekanowskialeans from the Middle Jurassic Yima Formation of Henan, China. Rev. Palaeobot. Palynol. 102. 179-187.

Zodrow, E.L., Mastalerz, M., 2007. Functional groups in a single pteridosperm species: variability and circumscription (Pennsylvanian, Nova Scotia, Canada). Int. J. Coal Geol. 70, 313-324.

Zodrow, E.L., D'Angelo, J.A., Mastalerz, M., Keefe, D., 2009. Compression-cuticle of seed ferns: Insights from liquid-solid states FTIR (Late Palaeozoic-Early Mesozoic Canada-Spain-Argentina). Int. J. Coal Geol. 79, 61-73.

Zodrow, E.L., D'Angelo, J.A., Mastalerz, M., Cleal, C.J., Keefe, D., 2010. Phytochemistry of the fossilized-cuticle frond Macroneuropteris macrophylla (Pennsylvanian seed fern, Canada). Int. J. Coal Geol. 84, 71-82.

Zodrow, E.L., D'Angelo, J.A., Taylor, W.A., Catelani, T., Heredia-Guerrero, J.A., Mastalerz, M., 2016. Secretory organs: Implications for lipoid taxonomy and kerogen formation (seed ferns, Pennsylvanian, Canada). Int. J. Coal Geol. 167 184-200.

Zodrow, E.L., D'Angelo, J.A., Cleal, C.J., 2017. 3D chemometric model and frond architecture of Alethopteris ambigua (Medullosales): Implications for reconstruction and taxonomy. Palaeontogr. B: Palaeobot. Palaeophytol. 295, 91-133. 